\title{
Fiscal policy rules in a stock-flow consistent model ${ }^{*}$
}

Sylvio Antonio Kappes ${ }^{\dagger}$

\author{
Marcelo Milan ${ }^{\ddagger}$
}

\begin{abstract}
This paper analyzes four fiscal policy rules in a Stock-Flow Consistent model. The rules are: (i) government expenditures as a fixed proportion of GDP; (ii) government deficit as a fixed proportion of GDP; (iii) government debt as a fixed proportion of GDP; and (iv) a balanced budget. Next, the economic trends implied by each rule are analyzed, and they are all compared. Some of the main findings of the exercise can be summarized as follows: the $a$ priori more expansionist (or less contractionist) rules present higher growth rates, ex post; there is an inverse relationship between government debt and firms' debt, with the former being higher under the first rule, and lower in the balanced budget rule, the opposite happening in the case of firms' debt. Finally, considering enterprises' profitability, we conclude that the best fiscal rule for firms is the first one, and, for the banking sector, not surprisingly, it is the balanced budget rule.
\end{abstract}

Keywords: Stock-Flow Consistent models; Fiscal policy

Jel Classification: B00, E12, E62.

${ }^{*}$ The authors acknowledge and are grateful to an anonymous referee for his/her comments and observations. They definitely contributed to improve the paper. All the usual disclaimers apply. A previous work that gave birth to the current article was ameliorated by the issues raised by Fernando Ferrari Filho, Antonio Carlos Macedo e Silva, and Louis-Philippe Rochon.

†Ph.D. Student, Graduate Program in Economics, UFRGS, sylviokappes@gmail.com

${ }^{\ddagger}$ Assistant Professor of Economics, Graduate Program in International Strategic Studies and Department of Economics and International Relations, UFRGS, milan.econ@gmail.com 


\section{Introduction}

In its latest country report about Brazil, the IMF stated that:

"Fiscal outcomes have been disappointing. In 2015 the nonfinancial public sector primary deficit reached 1.9 percent of GDP and the overall deficit was 10.4 percent of GDP. The primary deficit in 2016 is expected to reach 2.7 percent of GDP, and the overall balance would be close to that observed in 2015" (IMF, 2016, p.2).

And, as a consequence:

"The government that took office [but not by means of free elections] in May 2016 has announced a series of measures to address long standing fiscal imbalances and budget rigidities. A strong push to implement the proposed measures on the expenditure side would go a long way towards restoring policy credibility and market confidence with positive effects on investment and growth. Early implementation of key fiscal policy measures would also help moderate inflation expectations and facilitate monetary policy easing" (IMF, 2016, p.1, emphasis added by the authors).

Since May 2016, the government announced a series of measures to strengthen macro policies and restore credibility. Notably, the government has sent to Congress a constitutional amendment limiting the growth in federal noninterest spending to the rate of consumer price inflation of the previous year for the next 20 years. The government has also announced a reform of the social security system, needed in its own right and also necessary to make the expenditure limit viable (IMF, 2016, p.2).

To the best of our knowledge, neither the Brazilian government nor the IMF have provided any sound estimates regarding the short and long run impacts of those stringent fiscal measures. So, is there a coherent tool to think about macroeconomic policies such as those implemented in Brazil? The new government in Brazil adopted a full-fledged orthodox approach to macro policy, one that has been systematically rejected by the ballots ${ }^{1}$. So, it is not far fetched to assume that the new austerity policies are based on mainstream economics reasoning. Is this approach a reliable guide to fiscal policy?

Actually, it seems that the current state of mainstream macroeconomic theory is one of disarray. For instance, the Dynamic Stochastic General Equilibrium (DSGE) approach, the current workhorse of mainstream macro, has been challenged. Romer (2016) argues that "For more than three decades, macroeconomics has gone backwards" (p. 1), that "macroeconomists started invoking imaginary driving forces to explain fluctuations" (p. 15) and that "they seemed to forget things that had been discovered about the identification problem" (p. 15). Blanchard (2016) claims that he sees "the current DSGE models as seriously flawed" (p. 1) and criticizes their simplifying assumptions, their estimation method, their normative implications, and their bad appeal as a communication device 2 .

Is there any other approach able to deal coherently with macroeconomic theory and policy in general and fiscal policy in particular? It is the claim of this paper that the Stock-Flow Consistent (SFC) method can provide such framework. An advantage of such approach is that "[...]there are no black holes: every flow comes from somewhere and goes somewhere" (Godley, 1996, p. 7). According to Dos Santos (2002, p.1), SFC models are "crucial for sound macroeconomic reasoning in general and, therefore, its widespread adoption would increase both the transparency and the logical coherence of most macro models". Regarding macro

\footnotetext{
${ }^{1}$ And even the IMF has raised doubts about it (Ostry et al., 2016).

${ }^{2}$ A review of these critics is provided by Keen (2017).
} 
policy, SFC models are used also by central banks, like the Bank of England (see Burgess et al., 2016). And even by financial institutions, such as Goldman Sachs (see Hatzius and Stehn, 2012).

Following this path, in this paper the SFC method will be applied to study different fiscal policy rules, so that one can consider what is likely to happen, on a preliminary basis, in Brazil, although the austerity policy pursued in that country is not modeled because it does not fit any other previous experience ${ }^{3}$. Such a fiscal rule goes against recent empirical findings regarding the negative impact of austerity on output and employment, such as Blanchard and Leigh (2013), Borsi (2016) and Klein (2016). Therefore, the goal of the present paper is to analyze four different fiscal policy rules and their responses to adverse shocks in an SFC model. Our main inspirations are Godley and Lavoie (2007, chapter 11), Dafermos (2012), Le Heron (2012), and Pedrosa and Macedo e Silva (2014). Some of these works have carried out simulation exercises regarding fiscal rules, but we have a scenario (government spending as a fixed proportion of GDP) so far not considered in the literature.

The paper is organized as follows: the first section sets up the accounting framework and discusses the behavioral equations. The second section analyzes the evolution of the economy under four different fiscal rules: (i) government expenditures as a fixed proportion of GDP; (ii) government deficit as a fixed proportion of GDP; (iii) government debt as a fixed proportion of GDP; and (iv) a balanced budget ${ }^{4}$. The last section provides the concluding remarks.

\section{The model}

\subsection{The accounting framework}

Our model is made up of five sectors: households, firms, commercial banks, a central bank, and the government. The sectoral balance sheets are presented on table 1 below. Many simplifying assumptions are made. Just to mention a few: (i) households do not take loans and also (ii) do not hold cash; (iii) firms also do not hold cash and (iv) do not accumulate inventories; and (v) commercial banks do not issue equities.

Table 2 shown below represents the transactions-flow matrix of our fictional economy. The upper part represents current sales and purchases of goods and services and factors' payments. The middle part records the flows of financial payments. The lower part represents the changes in the stocks held by each sector.

Additional simplifying assumptions can be inferred from this second table. One of them is that banks' profits are completely distributed to households. The same happens between the central bank and the government. Finally, the model ignores inflation, utilizes a very straightforward portfolio choice for households, a very simple consumption function, and simplifies the wage bargaining process. Another drawback of our model is that the economy is closed. Moreover, households do not take loans, firms do not hold cash and do not accumulate

\footnotetext{
${ }^{3}$ The Washington Post called it the "mother of all austerity plans".

See < https://www.washingtonpost.com/news/worldviews/wp/2016/12/16/brazil-passes-the-motherof-all-austerity-plans/?utm_term=.f38a6cf8deb3>

${ }^{4}$ The fourth fiscal rule is the closest one to the aim of the Brazilian austerity plan. Since government outlays are constrained by last year inflation, and government revenues depend on nominal GDP (real GDP plus inflation), when the economy experiences real growth, revenues will raise faster than expenditures, eventually balancing the budget if this tendency turns out to happen. Of course, the path of nominal GDP depends on the very impacts of the austerity plan, and in this regard the fiscal policy is endogenized.
} 
inventories, all of them being unrealistic assumptions ${ }^{5}$. Also, there are no supply side constraints.

The equations that make this accounting structure up evolve through time and are discussed next.

2.2 The behavioral equations

\subsubsection{Equations for Households}

The first equation of the household sector is the definition of personal income:

$$
Y P=W B+F D_{f}+F_{b}+r_{d-1} D_{-1}+r_{b-1} B_{h_{-1}}
$$

Where YP is personal income, WB is wage bill, $F D_{f}$ is distributed profits of firms, $F_{b}$ represents the profits of banks, which we assume to be totally distributed to its owners, $r_{d}$ is the interest rate paid on deposits, $D$ is the stock of deposits, $r_{b}$ is the interest rate paid on government bonds, and $B_{h}$ are the bonds held by households.

The personal income is subject to taxation at rate $\theta$. The income left after taxation is the regular disposable income, $Y D_{r}$ :

$$
\begin{gathered}
Y D_{r}=Y P-T \\
T=\theta . Y P
\end{gathered}
$$

In addition to the regular sources of income, households might also increase their purchasing power by accrued capital gains CG in equity transactions. The summation of the regular disposable income with the capital gains gives an approximation to Haigh-Simons disposable income:

$$
\begin{gathered}
Y D_{h s}=Y D_{r}+C G \\
C G=\Delta p_{e} e_{d-1}
\end{gathered}
$$

The stock of wealth of households $V$ is the wealth of the previous period, plus the difference between Haigh-Simons disposable income and consumption C:

$$
V=V_{-1}+Y D_{h s}-C
$$

The consumption level depends on the lagged regular disposable income and on the lagged stock of wealth. This formulation considers that consumption depends on the lagged values of income and wealth. Many authors include contemporaneous values for both wealth and income in the function. Since there are no universal rules or recommendations regarding the format of the consumption function, we decide to use only lagged values:

\footnotetext{
${ }^{5}$ See Benati and Lubik (2014) for an empirical discussion of inventories. Denis and Silbikov (2009) discusses firms' cash holdings. See Mian, Sufi, and Verner (2015) for households debt.
} 


$$
C=\alpha_{1} Y D_{r-1}+\alpha_{2} V_{-1}
$$

Table 1. Balance sheet

\begin{tabular}{|c|c|c|c|c|c|c|}
\hline & Households & Firms & Banks & Government & $\begin{array}{l}\text { Central } \\
\text { bank }\end{array}$ & $\Sigma$ \\
\hline Deposits & $+\mathrm{D}$ & & $-D$ & & & 0 \\
\hline Tangible Capital & & $+K$ & & & & $+\mathrm{K}$ \\
\hline Equities & $+\mathrm{e}$ & $-\mathrm{e}$ & & & & 0 \\
\hline $\begin{array}{l}\text { Treasury bills } \\
\text { High-powered }\end{array}$ & $+B_{h}$ & & $+\mathrm{B}_{\mathrm{b}}$ & $-B$ & $+\mathrm{B}_{\mathrm{cb}}$ & 0 \\
\hline money & & & $+\mathrm{H}_{\mathrm{b}}$ & & $-\mathrm{H}$ & 0 \\
\hline CB advances & & & $-A$ & & $+A$ & 0 \\
\hline Loans & & $-\mathrm{L}$ & $+\mathrm{L}$ & & & 0 \\
\hline Balance & $-V$ & $-V f$ & 0 & $-B$ & 0 & $+\mathrm{K}$ \\
\hline
\end{tabular}

Source: Elaborated by the authors.

Table 2. Transactions flow

\begin{tabular}{|c|c|c|c|c|c|c|c|c|c|}
\hline & & \multirow[t]{2}{*}{ Households } & \multicolumn{2}{|c|}{ Firms } & \multirow[t]{2}{*}{ Banks } & \multirow[t]{2}{*}{ Government } & \multicolumn{3}{|c|}{ Central bank } \\
\hline & & & Current & Capital & & & Current & Capital & $\Sigma$ \\
\hline Consumption & & $-\mathrm{C}$ & $+\mathrm{C}$ & & & & & & 0 \\
\hline \multicolumn{10}{|l|}{ Government } \\
\hline expenditures & & & $+\mathrm{G}$ & & & $-G$ & & & 0 \\
\hline Investment & & & +1 & -1 & & & & & 0 \\
\hline Taxes & & $-\mathrm{T}$ & & & & $+\mathrm{T}$ & & & 0 \\
\hline Wages & & $+W B$ & $-W B$ & & & & & & 0 \\
\hline Firms' profits & & $+\mathrm{FD}_{\mathrm{f}}$ & $-F_{f}$ & $+\mathrm{FU}_{f}$ & & & & & 0 \\
\hline \multicolumn{10}{|l|}{ Banks' } \\
\hline profits & & $+\mathrm{Fb}$ & & & $-\mathrm{Fb}$ & & & & 0 \\
\hline \multicolumn{2}{|c|}{ Central bank's profits } & & & & & $+\mathrm{Fcb}$ & - Fcb & & 0 \\
\hline \multirow{7}{*}{ Interest on } & & & & & $-\quad r_{d-}$ & & & & \\
\hline & & & & & $+r_{1-1} \cdot L$ & & & & \\
\hline & Loans & & $-r_{1-1} \cdot L_{-1}$ & & & & & & 0 \\
\hline & & & & & $-\quad r_{A-}$ & & $+r_{A-1} \cdot A$ & & \\
\hline & advances & & & & 1. $\mathrm{A}_{-1}$ & & & & 0 \\
\hline & Treasury & & & & $+r_{b-}$ & & $+\quad r_{b-}$ & & \\
\hline & bills & $+r_{b-1} \cdot B_{h-1}$ & & & ${ }_{1} \cdot B_{b-1}$ & $-r_{b-1} \cdot B_{-1}$ & ${ }_{1} \cdot \mathrm{B}_{\mathrm{cb}-1}$ & & 0 \\
\hline Change in & Deposits & $-\Delta \mathrm{D}$ & & & $+\Delta \mathrm{D}$ & & & & 0 \\
\hline \multirow{9}{*}{ the stocks of } & Loans & & & $+\Delta \mathrm{L}$ & $-\Delta \mathrm{L}$ & & & & 0 \\
\hline & $\begin{array}{l}\text { High- } \\
\text { powered }\end{array}$ & & & & & & & & \\
\hline & money & & & & $-\Delta H_{b}$ & & & $+\Delta \mathrm{H}$ & 0 \\
\hline & Treasury & & & & - & & & - & \\
\hline & bills & $-\Delta \mathrm{B}_{\mathrm{h}} \cdot \mathrm{p}_{\mathrm{B}}$ & & & $\Delta \mathrm{B}_{\mathrm{b}} \cdot \mathrm{p}_{\mathrm{B}}$ & $+\Delta \mathrm{B} \cdot \mathrm{p}_{\mathrm{B}}$ & & $\Delta \mathrm{B}_{\mathrm{cb}} \cdot \mathrm{p}_{\mathrm{B}}$ & 0 \\
\hline & & & & & & & & & \\
\hline & advances & & & & $+\Delta \mathrm{A}$ & & & $-\Delta \mathrm{A}$ & 0 \\
\hline & & & & + & & & & & \\
\hline & Equities & $-\Delta$ e.p $p_{e}$ & & $\Delta$ e. $p_{e}$ & & & & & 0 \\
\hline$\Sigma$ & & 0 & 0 & 0 & 0 & 0 & 0 & 0 & 0 \\
\hline
\end{tabular}

Source: Elaborated by the authors.

The wealth of households is allocated between government bonds $B_{h}$, firms' equities $e_{d}$ and banking deposits $D$. We simplify the portfolio choice, assuming that households want to hold a fixed proportion of bonds and equities, according to its Perceived Degree of Uncertainty (PDU). Banking deposits are a residual. 


$$
\begin{gathered}
B_{h}=\left(h_{10}+h_{11} \cdot P D U\right) \cdot V_{-1} \\
e_{d}=\left(h_{20}-h_{21} \cdot P D U\right) \cdot V_{-1} \\
D=V-B_{h}-e_{d}
\end{gathered}
$$

The PDU is employed by Dafermos (2012) in his discussion about the linkages between liquidity preference, uncertainty, and recession. We utilize this variable in almost all the equations of this paper: in households' portfolio choice, in firms' investment decision, and in banks' credit rationing and excess reserves holdings. The correspondence, though, is not perfect, since our model is simpler than the one proposed by Dafermos (2012). Like him, we assume that PDU is the same for all sectors.

In SFC models, households' portfolio choice is usually done along Tobinesque lines. Here, though, we avoid the complications that arise from this approach, following instead an uncomplicated modeling approach, similar to the one presented in Dos Santos and Zezza (2008) and Pedrosa and Macedo e Silva (2014).

\subsubsection{Equations for Commercial Banks}

The first equation here follows directly from the accounting framework: banks' profits are composed of the interest rate charged on loans to firm $\left(r_{1}\right)$ multiplied by the stock of loans plus the interest receipts from its holdings of government bonds $\left(B_{b}\right)$, minus the interest paid on deposits and on central bank advances $(A)$.

$$
F_{b}=r_{l-1} L_{-1}+r_{b-1} B_{b-1}-r_{d-1} D_{-1}-r_{A-1} A_{-1}
$$

The new loans given to firms are subject to a credit rationing, which depends on the PDU, on the leverage ratio of firms $(L / K)$ and on the basic interest rate. The stock of loans at the end of the period $(L)$ is the previous period stock minus repayments (rep), plus the new loans given out in the current period. This formulation is based on Dafermos (2012) and Le Heron and Mouakil (2008).

$$
\begin{gathered}
C R=\rho_{1} P D U+\rho_{2}\left(L_{-1} / K_{-1}\right)+\rho_{3} r_{b} \\
N L=L_{D}(1-C R) \\
L=(1-\text { rep }) L_{-1}+N L
\end{gathered}
$$

Banks' holdings of high powered money are composed of reserve requirements upon deposits $(\mu)$ and excess reserves, $\eta$. The amount of excess reserves depends positively on the PDU and negatively on the basic interest rate:

$$
H_{b}=(\mu+\eta) \cdot D
$$




$$
\eta=\eta_{0}+\eta_{1} P D U-\eta_{2} r_{b}
$$

We distinguish between two cases regarding the demand for government bonds and central bank advances. If deposits net of required reserves are higher than loans, banks will use these extra resources to acquire government bonds and advances will be equal to excess reserves. But if loans are higher than deposits net of required reserves, no government bonds are held and central bank advances are demanded to fill the gap.

$$
\begin{gathered}
B_{b n}=D-\mu . D-L \\
B_{b}=\left\{\begin{array}{rr}
B_{b n}, & B_{b n} \geq 0 \\
0, & B_{b n}<0
\end{array}\right. \\
A=\left\{\begin{array}{rr}
\eta \cdot D, & B_{b n} \geq 0 \\
H_{b}+L-D, & B_{b n}<0
\end{array}\right.
\end{gathered}
$$

Discussing the first case above, Dafermos (2012), who uses the same approach, argues that:

"the amount of excess reserves represents the cash not lent by banks in a surplus position to their counter-parties in a deficit position. Thus, a specific amount of excess reserves translates into an equivalent amount of advances, which the banks in a deficit position are forced to get from the central bank" (Dafermos, 2012; p. 766).

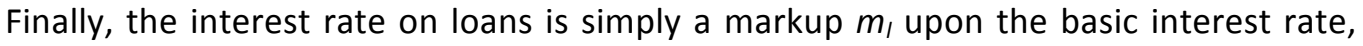
whereas the interest rate paid on deposits is the basic interest rate minus a spread $m_{d}$.

$$
\begin{gathered}
r_{l}=r_{b}+m_{l} \\
r_{d}=r_{b}-m_{d}
\end{gathered}
$$

\subsubsection{Equations for Firms}

We start our discussion of firms' equations with their costs, which are very simplified in our model. The wage bill of the economy is the average wage times the number of employed workers. We assume that wages grow exogenously with labor productivity, and that the number of employed workers is the output $Y$ divided by the labor productivity. The latter is the only source of exogenous growth in the model.

$$
\begin{gathered}
W B=N . W \\
W=W_{-1}\left(1+g_{p r}\right)
\end{gathered}
$$




$$
\begin{gathered}
N=\frac{y}{p r} \\
p r=p r_{-1}\left(1+g_{p r}\right)
\end{gathered}
$$

The productivity of labor grows at an exogenous rate $g_{p r}$. In the calibration process, we assume that this ratio is $1,85 \%$. According to Cavalcante and De Negri (2014, p. 149), this was the Brazilian labor productivity growth rate between 2001 and 2011.

We assume that the production of firms is sold out each period, and is distributed between households' consumption, firms' investment ( $I$ ), and government purchases $(G)$. Subtracting the wage costs and the interest on loans from output, it gives us the definition of firms' profits. A proportion $s_{f}$ of them is retained by the firm, and the rest of it is distributed to households ${ }^{6}$.

$$
\begin{gathered}
Y=C+I+G \\
F_{f}=Y-W B-r_{l-1} L_{-1} \\
F U_{f}=s_{f} F_{f} \\
F D_{f}=F_{f}-F U_{f}
\end{gathered}
$$

The function for desired investment $\left(i_{d}\right)$ is the most complex one. It depends on the lagged capacity utilization ${ }^{7}$, on the undistributed profits normalized by the nominal capital stock, on the interest rate on loans, and on a parameter $b_{0}$ which represents the "animal spirits" of the entrepreneurs. This last parameter depends on a constant $\chi_{0}$ and on the PDU. The rate of capacity utilization is a little cumbersome and defined as the ratio between output $(Y)$ and potential output-capital ratio $(v)$ times the stock of capital $(K)$.

$$
\begin{gathered}
i_{d}=\left(\beta_{0}+\beta_{1} u_{-1}+\beta_{2}\left(\frac{F U_{f}}{K_{-1}}\right)-\beta_{3} r_{l}\right) \cdot K_{-1} \\
\beta_{0}=\chi_{0}-\chi_{1} \cdot P D U \\
K=K_{-1}+I
\end{gathered}
$$

\footnotetext{
${ }^{6}$ See Lavoie (2008) for a discussion about how financialisation have changed firms' behavior regarding these ratios.

${ }^{7}$ This equation is based on Lavoie and Godley (2001-02). The only difference is that we simplified away the influence of Tobin's $q$. It is important to notice that the desired investment is a function of capacity utilization regardless of the levels of the latter. This is clearly unrealistic and has some important implications for what comes next.
} 


$$
u=\frac{Y}{v \cdot K_{-1}}
$$

Investment can be financed by loans, retained profits, and issuance of equities. We treat the demand for loans as the residual of the financing decisions, and it is subject to the above described credit rationing by banks. The realized investment is thus influenced by the amount of loans that the firms actually receive.

$$
\begin{gathered}
L_{D}=I_{d}-F U_{f}-p_{e} \Delta e+\text { rep. } L_{-1} \\
I=\Delta L+F U_{f}+p_{e} \Delta e
\end{gathered}
$$

Following Dos Santos and Zezza (2008, p. 454) and Pedrosa and Macedo e Silva (2014, p. 7), we assume that firms keep a fixed proportion $x$ between equities and the stock of capital. Equities' price is given by the interaction of demand and supply.

$$
\begin{gathered}
e=x \cdot k_{-1} \\
p_{e}=\frac{e_{d}}{e}
\end{gathered}
$$

\subsubsection{Equations for Central Bank}

The Central Bank makes profits, $F_{c b}$, which are completely distributed to the government. They are composed of the interest receipts upon the advances given to the commercial banks and the earnings from governments' bonds held.

$$
F_{c b}=r_{A-1} A_{-1}+r_{b-1} B_{c b-1}
$$

We assume, for simplicity, that the interest rate on central bank advances $\left(r_{A}\right)$ is the same as the interest on governments' bonds.

$$
r_{A}=r_{b}
$$

All the high-powered money demanded by commercial banks is supplied (assuming therefore full accommodation, highlighting the endogenous nature of money supply) .

$$
H=H_{b}
$$

We assume that the central bank is the residual purchaser of government bonds ${ }^{8}$.

\footnotetext{
${ }^{8}$ Thus, the central bank can run out of government's bonds if the other sectors purchase all the outstanding issues. In this case, we can assume that monetary policy is conducted via reserves' remuneration, rather than by open market operations.
} 


$$
B_{c b}=B-B_{h}-B_{b}
$$

The stock of bonds is the stock of the previous period plus the fiscal result of the government $(D G)$.

$$
B=D G+B_{-1}
$$

The redundant equation, implied by all the others, is the one that guarantees the closure of central bank's balance sheet:

$$
H=A+p_{b} B_{c b}
$$

\subsubsection{Equations for Government}

Our intention is to analyze the dynamics that arise from different fiscal policy rules. We study four cases, drawing heavily on Le Heron (2012). Under the first rule, the government seeks to maintain a fixed proportion of spending relative to GDP, that is, a fixed proportion of $\mathrm{G} / \mathrm{Y}$.

$$
\begin{gathered}
G=\sigma_{1} Y_{-1} \\
D G=G+\left(r_{b-1} B_{-1}\right)-T-F_{c b}
\end{gathered}
$$

The second rule is one in which the government has a target proportion for deficit. In this case, we have:

$$
\begin{gathered}
G=D G-\left(r_{b-1} B_{-1}\right)+T+F_{c b} \\
D G=\sigma_{2} Y_{-1}
\end{gathered}
$$

Under the third rule, the fixed proportion is related to the debt (target debt, $\mathrm{B}^{\top}$ ):

$$
\begin{gathered}
G=D G-\left(r_{b-1} B_{-1}\right)+T+F_{c b} \\
D G=\Delta B \\
\Delta B=B^{T}-B_{-1} \\
B^{T}=\sigma_{3} Y_{-1}
\end{gathered}
$$


Finally, the last rule is the one where the budget is balanced:

$$
\begin{gathered}
G=T+F_{c b}-r_{b-1} B_{-1} \\
\Delta B=0
\end{gathered}
$$

Simulating different fiscal policy rules in a SFC model is not a novel exercise. Le Heron (2012) carried out a similar procedure, comparing six different rules. The targets for deficit and for debt, as well as the balanced budget, were analyzed by him. Our rule of a fixed proportion of spending relative to GPD is innovative when compared to this author. Pedrosa and Macedo e Silva (2014) also compared three fiscal rules, none of them similar to ours. They considered (i) government expenditures as a constant fraction of the capital stock, (ii) government expenditures varying according to deviations of capacity utilization from its long-term trend, and (iii) an austerity case, where expenditures decrease if the lagged public debt increased. The second rule analyzed by the authors show a different treatment for the investment function. Anyway, since in all four regimes the fiscal result is attached to income (government spending is on the demand side of the income identity and taxes depend on income), fiscal policy becomes fully endogenized.

\subsection{A note on the calibration of the model}

It must be remarked that only a few parameters of the model represent a real economy, since the exercise is supposed to be generic enough to account for many real-world economies. However, since the goal of the simulation is to shed some light on the likely outcomes of Brazilian austerity policies, the values of the parameters $\sigma_{i}$ are the mean value of the government's purchases share in output, government deficit, and government debt for Brazil from 2006 to $2016^{9}$. The labor productivity growth rate, the only exogenous growth variable, as mentioned above, is taken from Cavalcante and De Negri (2014). The simulation starting values for households' consumption, firms' investment, and government purchases represent an approximate proportion of these entries from the Brazilian national accounts ${ }^{10}$.

The majority of our parameters have the same value as those in Dafermos (2012), but parameters from Godley and Lavoie (2007, cp. 11), Le Heron (2012), and Pedrosa and Macedo e Silva (2014) were also used.

\section{The behavior of the model under the different fiscal rules}

Our goal here is to run the model with the four fiscal rules discussed above. All simulations have the same initial values for the endogenous variables, the same parameters, and the same equations, except, of course, for the fiscal policy equations. Thus, the differences that arise are exclusively due to the fiscal rules themselves.

It is important to note that the time frame of the graphs is fictitious. Here, we follow the time frame of Dafermos (2012), running the model for 510 periods, from 1500 to 2010. The label in itself is just a convenience and do not represent the number of times that the earth revolves around the sun. It could range from 1 to 510 without any change in the results. Other authors, like Godley and Lavoie (2007), use periods that run from 1950 to 2010.

\footnotetext{
9 The data are available at < http://sidra.ibge.gov.br> and at <http://www.bcb.gov.br/pt$\mathrm{br} / \# ! / \mathrm{n} / \mathrm{SERIESTEMPORAIS>}$

${ }^{10}$ They are approximate proportions because our model represents a closed economy. The Brazilian output share corresponding to the external sector was split in equal parts to aggregate demand from households, firms, and government in the calibration of the model.
} 
The discrepancies between the output growth rates for the four rules are significant, as can be seen on figure 1. The initial soaring in the growth rates is caused by the reinforcing role of consumption and investment growth, which causes output to increase and, in the next period, generates higher government expenditures. The reduction in the pace of growth rate is caused by a deceleration in consumption growth, which is caused by lower increases in households' income. In the steady state, the fixed $G / Y$ ratio rule gives the higher value: $3.53 \%$ per annum. Next, we have a fixed $D G / Y$ ratio rule with $2.96 \%$ growth; a target for $B / Y$ rule with $2.3 \%$ and the balanced budget rule (eq.) with a meager $2.06 \%$.

Figure 1. GDP growth rate under the four fiscal rules

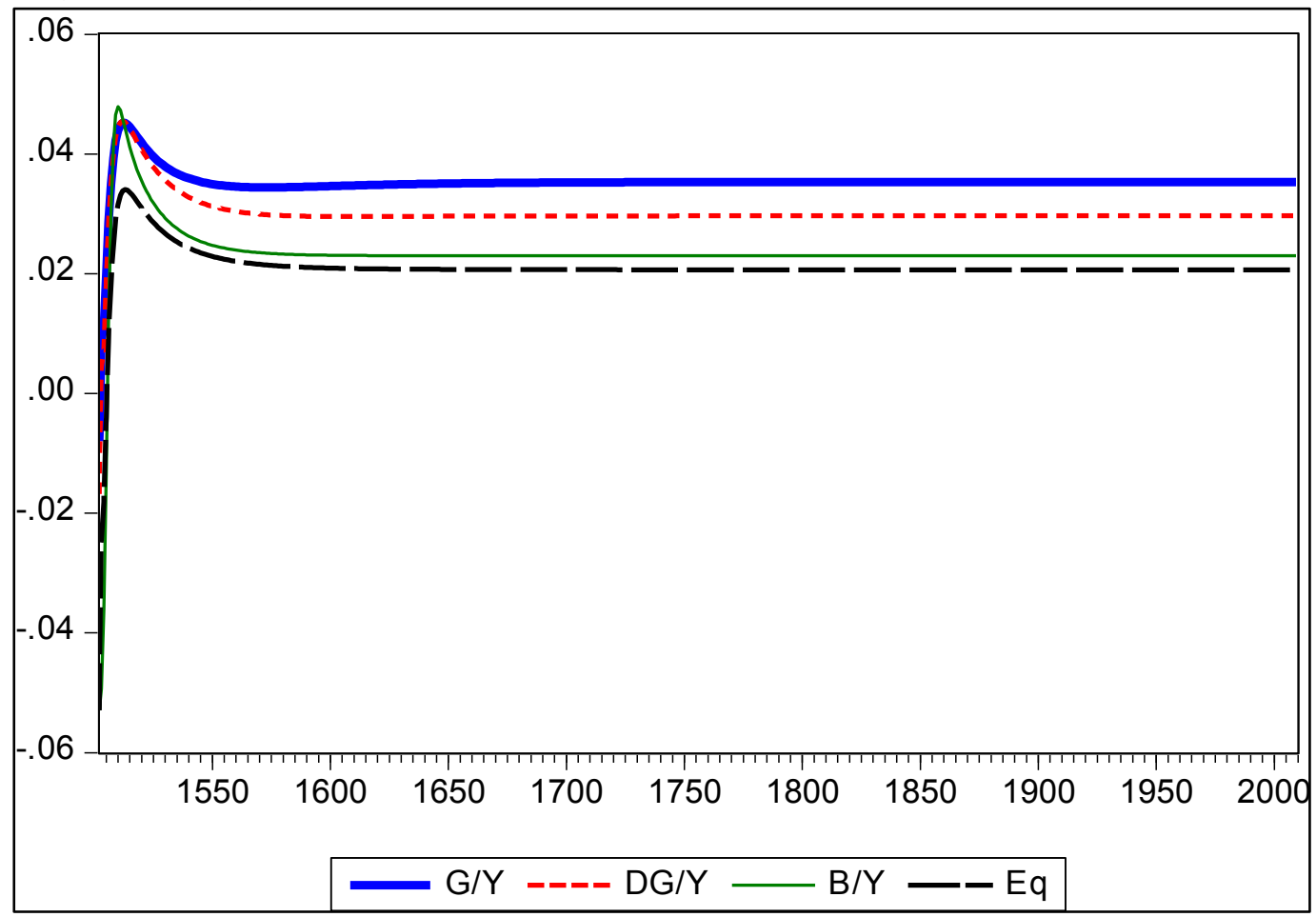

Source: Elaborated by the authors using Eviews.

The growth patterns have different impacts on the capacity utilization of firms. Regarding this variable, the fiscal rules rank the same way as above, with the fixed proportion of government purchases over GDP (G/Y) at the top and the balanced budget at the bottom (figure 2). The rates of utilization are, respectively, $0.85 ; 0.68 ; 0.5$; and 0.45 . The initial fall both in the $B / Y$ and in balanced budget rules is caused by negative growth rates, which is due to government restrictive purchases in order to meet its debt target $(\mathrm{B} / \mathrm{Y}$ rule) or to maintain the budget balanced. It is important to note that the starting point of the capacity utilization is extremely low, but the first rule was compatible with 'normal' values, whereas the third one achieved a mild growth and the last one contributes to a state of permanently depressed capacity utilization. 
Figure 2. Capacity utilization under the four fiscal rules

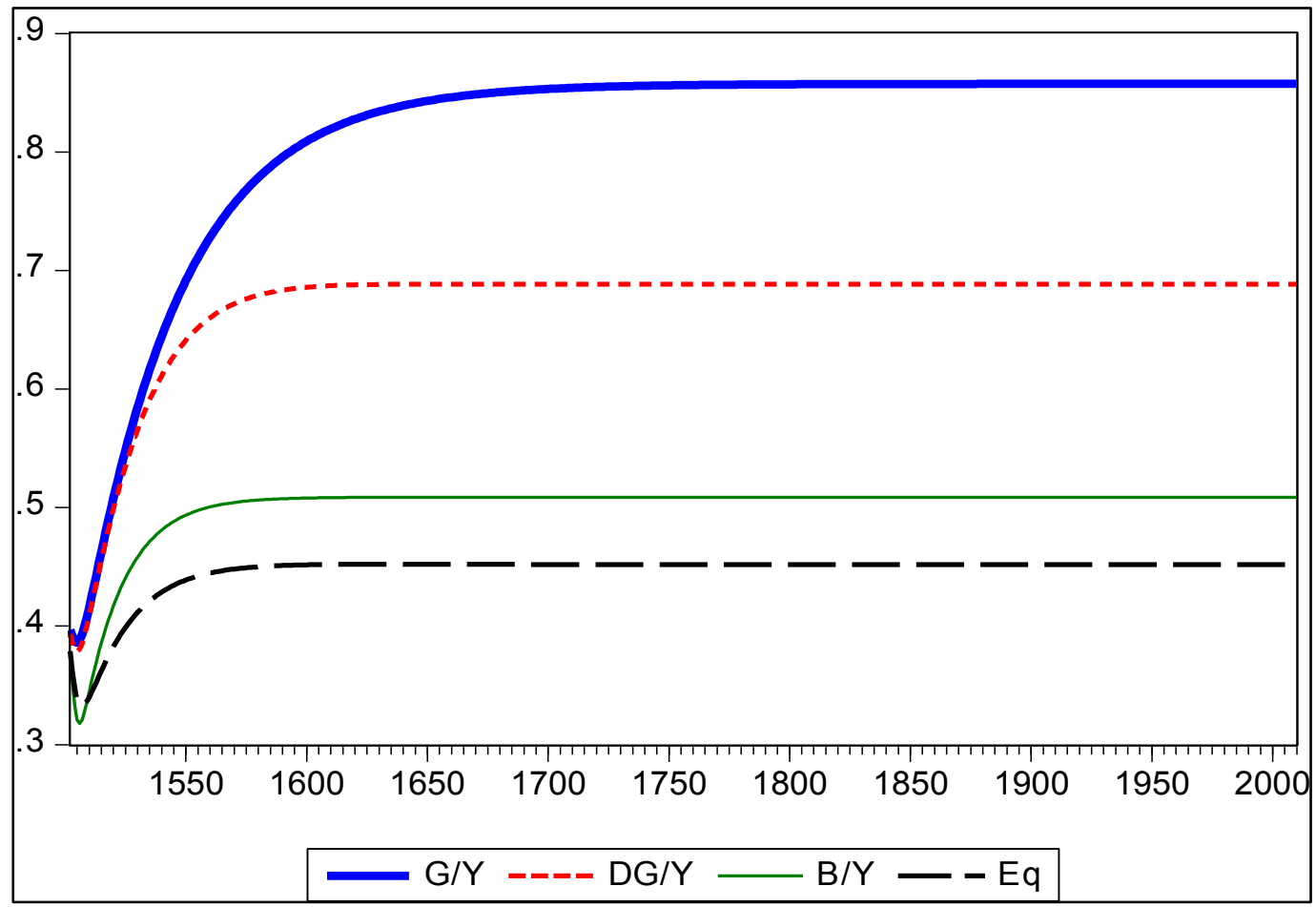

Source: Elaborated by the authors using Eviews.

The aggregate demand composition also differs among the fiscal rules. The highest consumption share (defined as the value of consumption divided by the value of the output) is the one generated by the $B / Y$ and balanced budget rules, which also present the highest share of investment rate (figures 3 and 4). The $G / Y$ and DG/Y rules present the highest government expenditures share of output (figure 5). Nonetheless, the four fiscal rules present an investment trajectory that is incompatible with a rapid growing economy. So, public investment must perform a relatively high share of government outlays to contribute to growth. Since government spending share of output is relatively small even under the less contractionary rule, this means that household consumption might be crowding out private investment in terms of some durable goods.

There is an apparent paradox here. According to Kalecki (1965) and Steindl (1952), higher capacity utilization rates lead to higher investment. Our model, however, presents a different result: the rules with the smaller steady-state capacity utilization rates are the ones with the higher investment share in output. However, if we take the investment relative to the stock of capital (instead of output), we get an opposite ranking of the regimes, with the $G / Y$ regime in the highest position and the balanced budget regime in the lowest position (figure 6). The conundrum remains, however. One might wonder why there is still investment, given the sky-high levels of idleness. In our investment function, there is not a target level for the capacity utilization, that is, it does not converge to any specific value. This might suggest that the investment function is neo-Kaleckian. But this is not the case. We assume that the interest rate is relevant for investment decisions, for example. A possible answer to this difficulty is Marx's argument that investment is compulsory under capitalist (Crotty, 1993). With very low levels of capacity utilization, competition will be fierce and firms will struggle for market share, introducing innovations. This can only be done by recourse to capital expenditures that are both cost-cutting and capacity reducing. Our exercise, however, provides simulation only about levels of investment, not the composition of these expenditures. So, we can only come up with conjectures at this point. But this definitely needs improvements. 
Figure 3. Consumption as share of output under the four fiscal rules

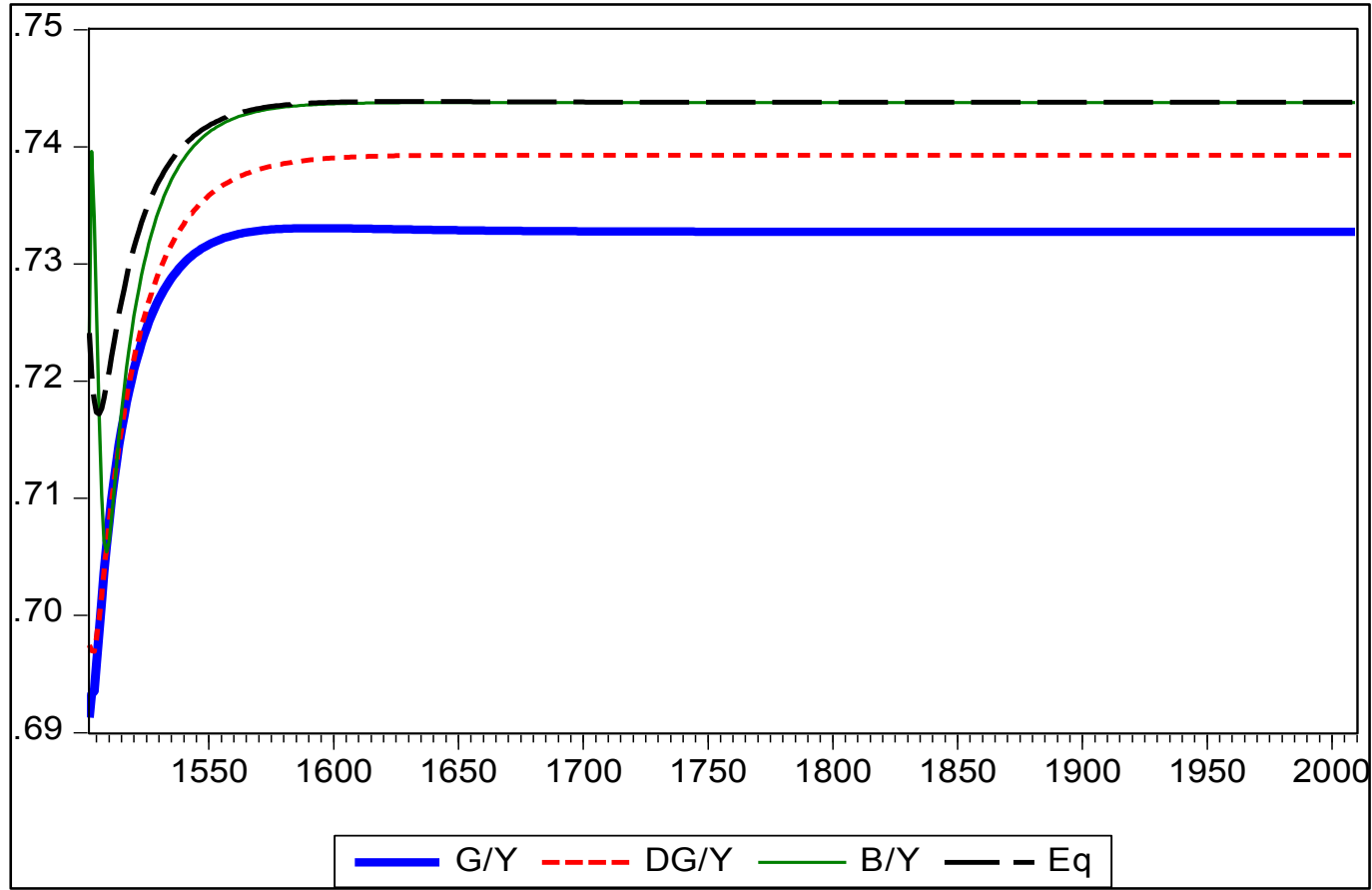

Source: Elaborated by the authors using Eviews.

Figure 4 .Investment rates under the four fiscal rules

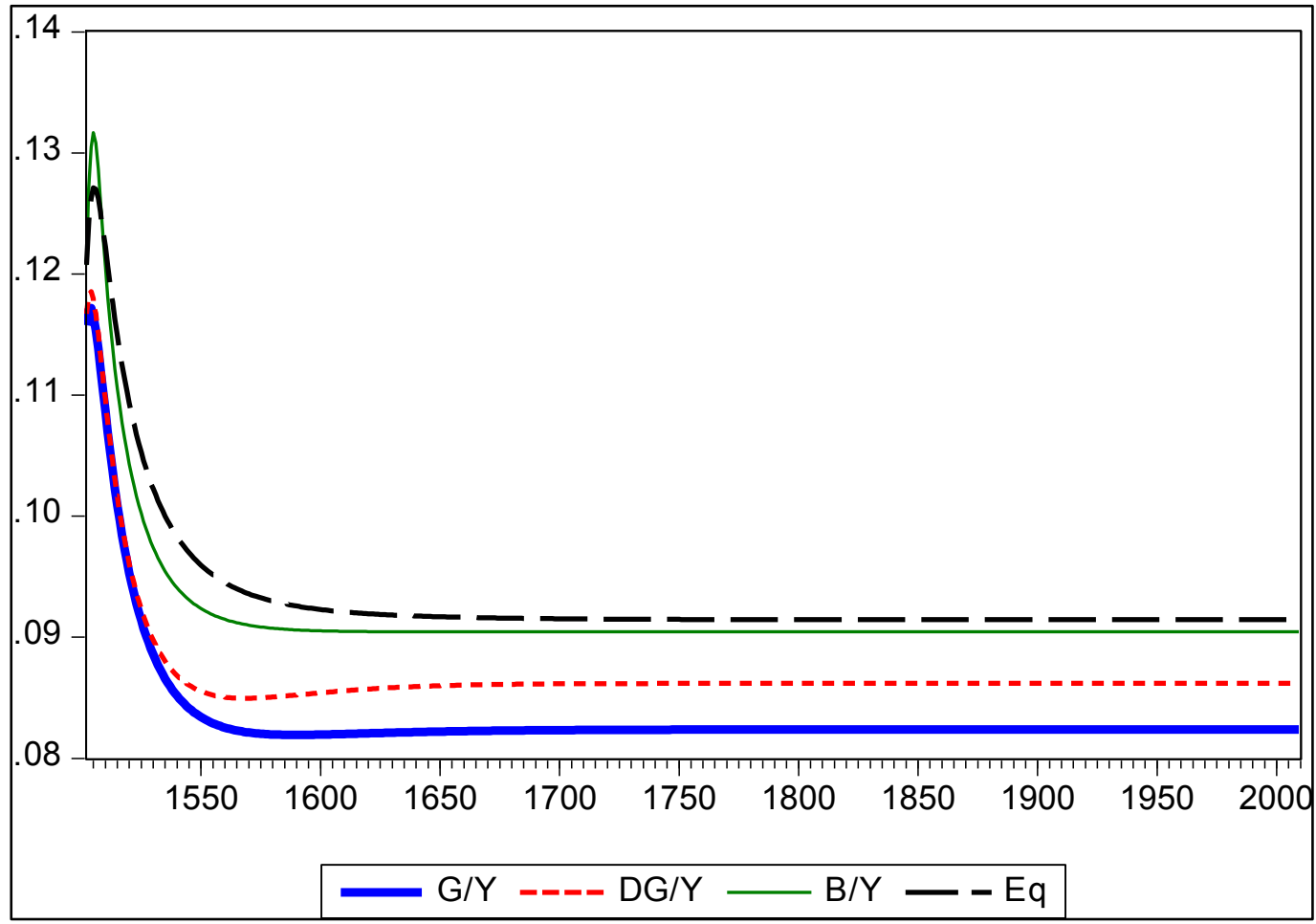

Source: Elaborated by the authors using Eviews. 
Figure 5. Government expenditures as share of output under the four fiscal rules

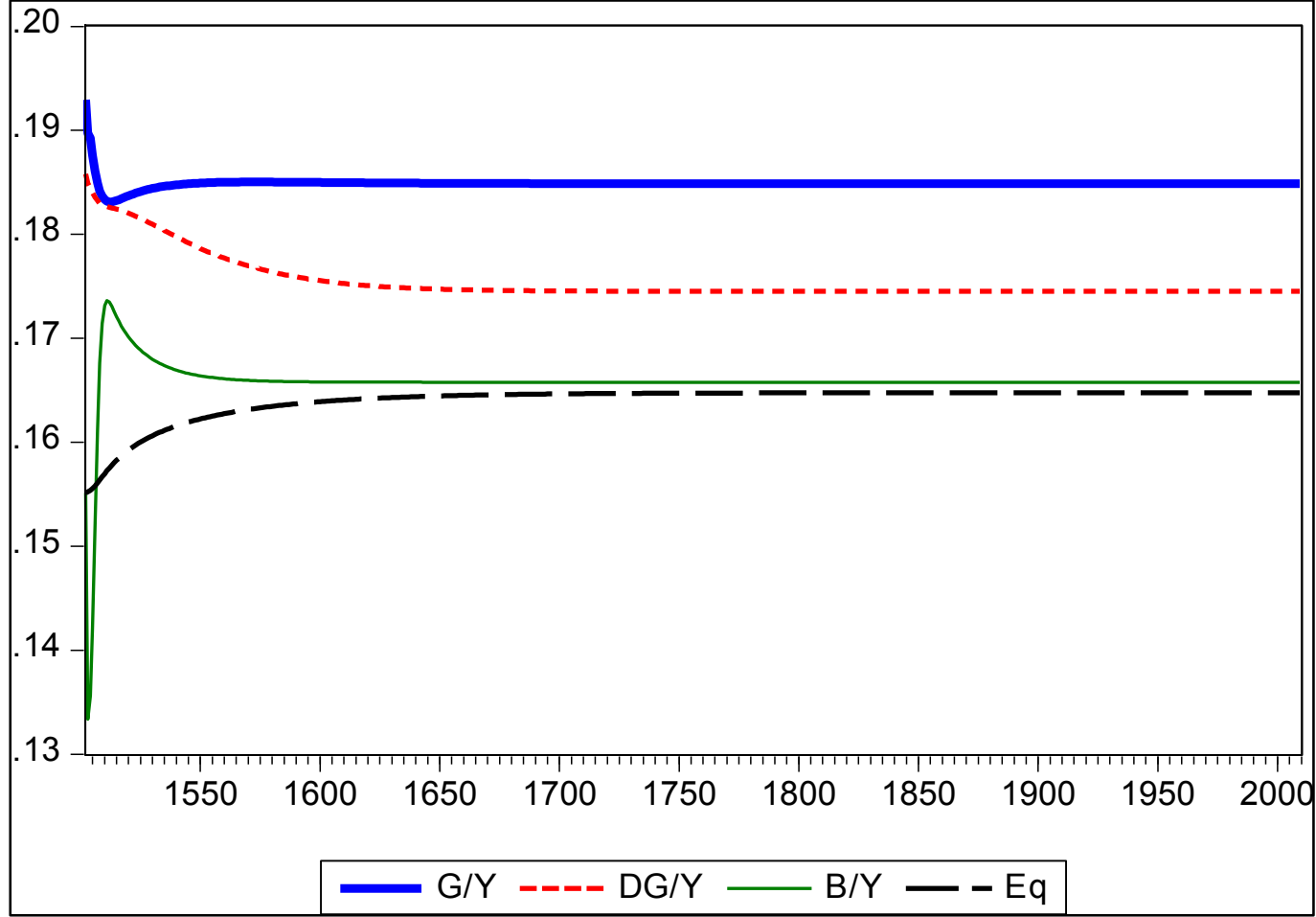

Source: Elaborated by the authors using Eviews.

Figure 6. Investment relative to the stock of capital under the four fiscal rules

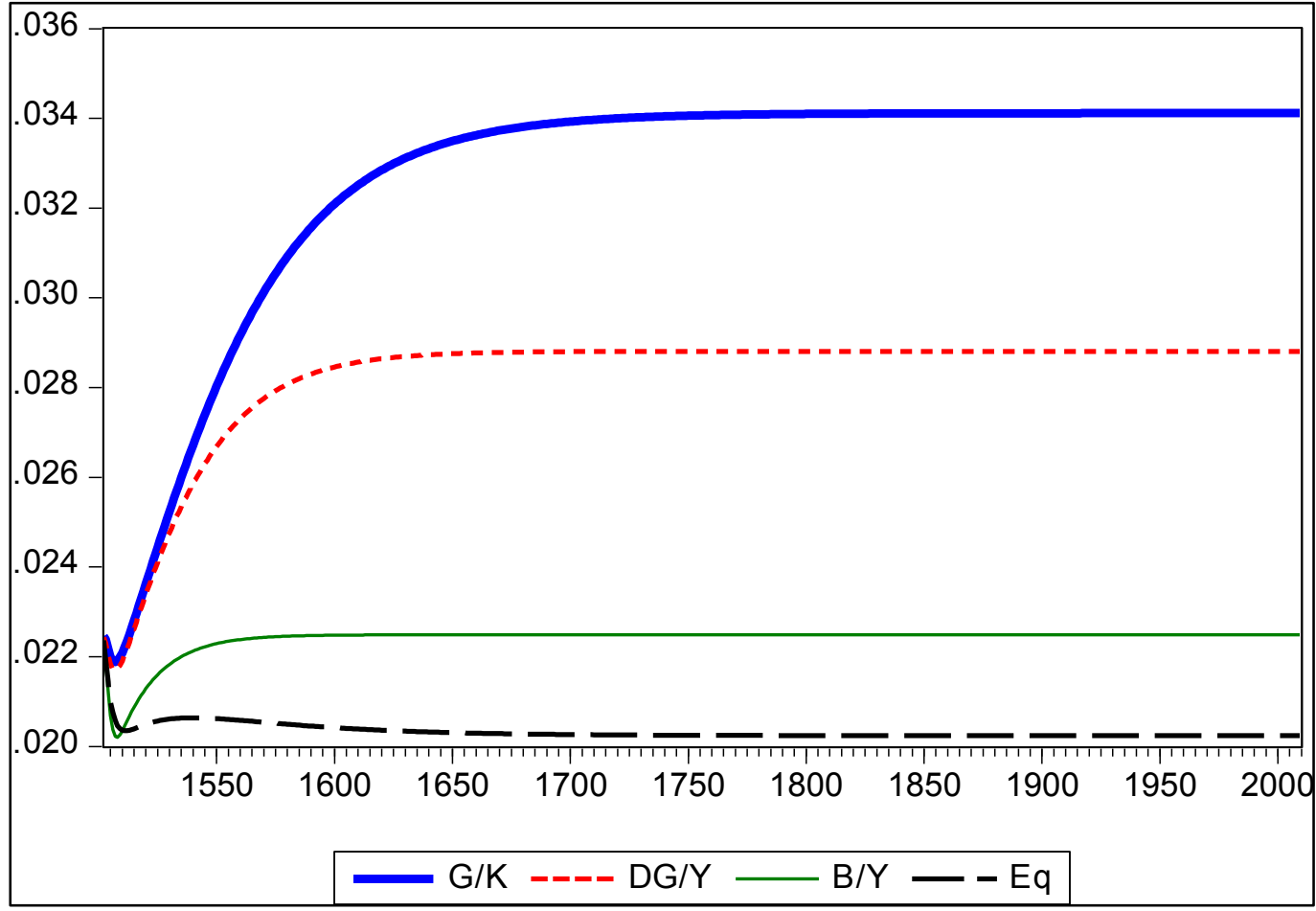

Source: Elaborated by the authors using Eviews.

A consequence of the higher (lower) output growth rates and capacity utilization is the higher (lower) profitability of firms, here defined as the ratio of profits to the stock of capital $\left(F_{f} / K\right)$. It is interesting to note that this result was predicted by Kalecki (1965), who argued that 
public expenditures generate higher entrepreneurial profits. This is precisely what happens here: the regime with the highest steady-state government expenditures as share of output ( $G / Y$ regime) has also the highest profitability for firms (figure 7).

Figure 7. Firms' profitability under the four fiscal rules

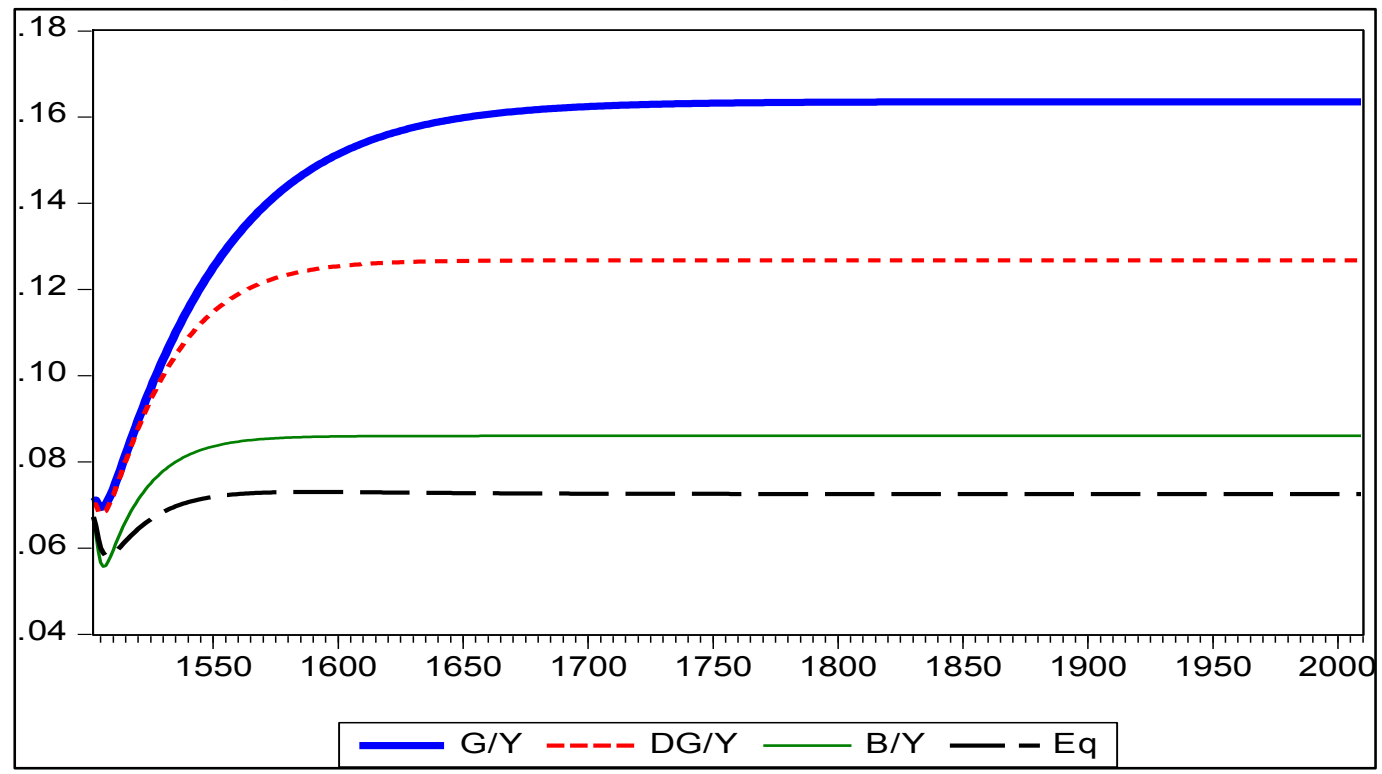

Source: Elaborated by the authors using Eviews.

The government debt relative to the stock of capital is obviously dissimilar among the fiscal rules. The first rule $(G / Y)$ is the one that generates the highest public debt as a percentage of capital stock (0.54), followed by the deficit target $(0.33)$ and by the debt target (0.08). The government debt in the balanced budget of course approaches zero in the steady state (figure 8).

Figure 8. Government debt relative to the stock of capital under the four fiscal rules

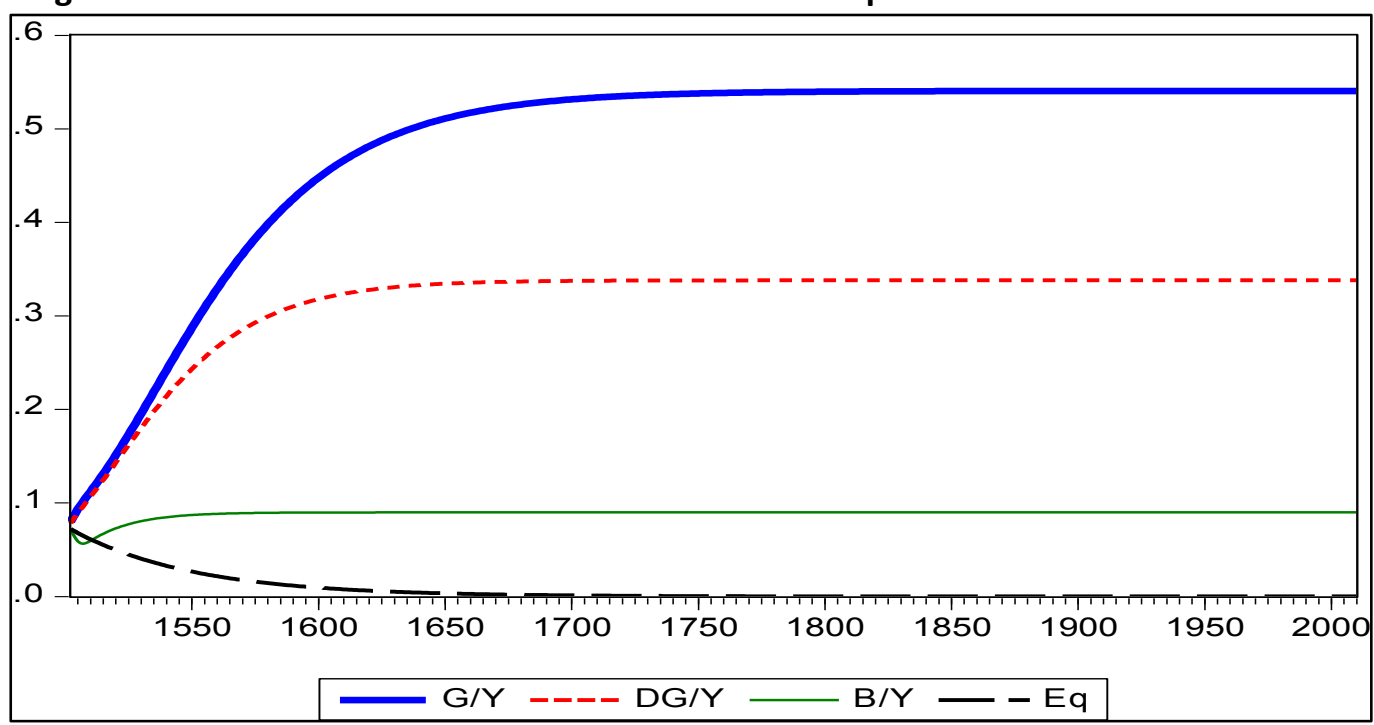

Source: Elaborated by the authors using Eviews.

Since government bonds are a significant part of households' wealth, it is expected that the ratio $\mathrm{V} / \mathrm{K}$ would change under the fiscal rules. The rank of rules regarding this ratio is the same outlined above: fixed $G / Y$ in the first position, and the balanced budget rule in the last place (figure 9). 
Figure 9. Households' wealth relative to the stock of capital of the economy under the four fiscal rules

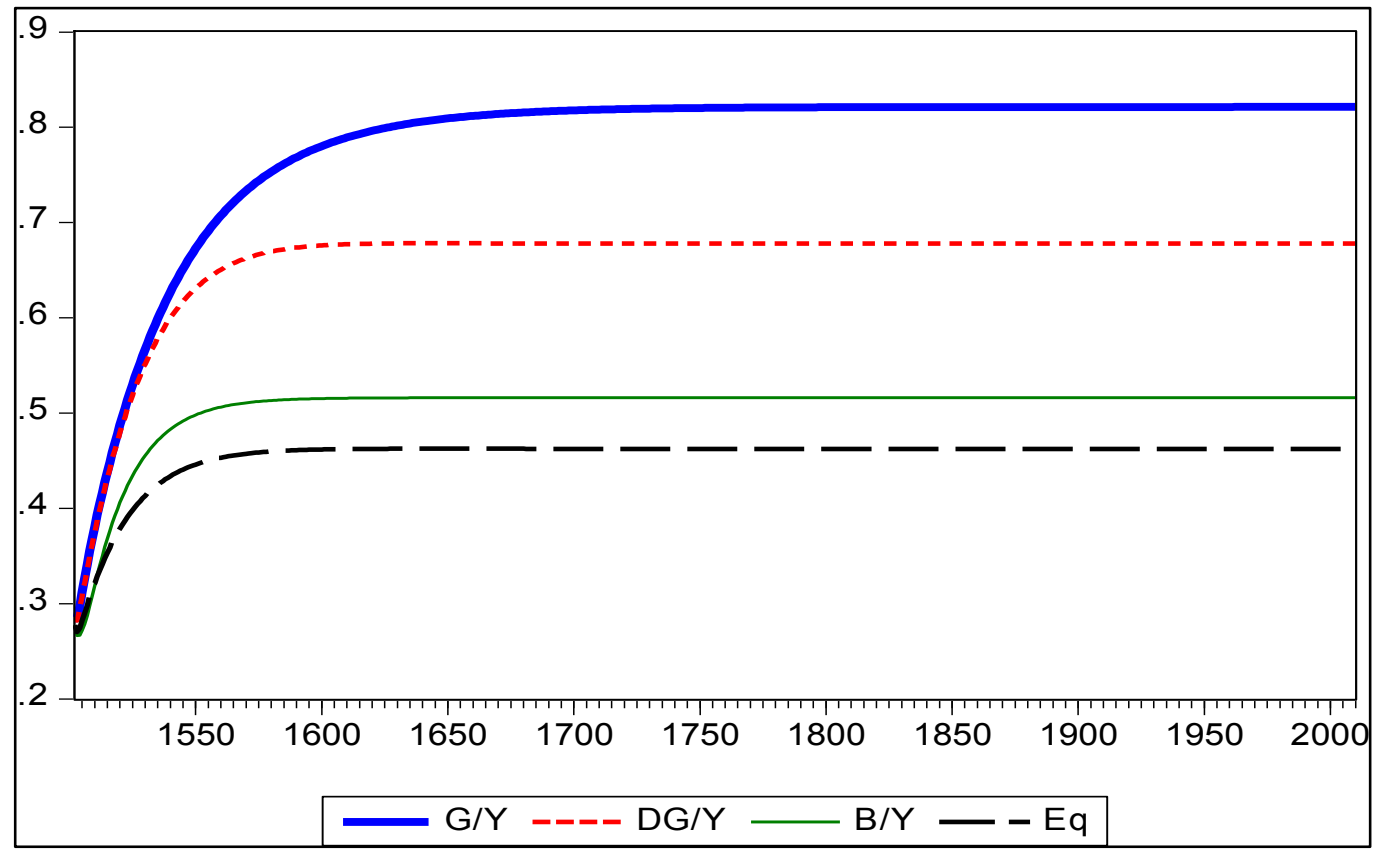

Source: Elaborated by the authors using Eviews.

The composition of households wealth also differs when the fiscal rule changes. Banks' deposits have its highest importance in the balanced budget rule. This is a consequence of the simple portfolio choice adopted in the model: households want to hold a fixed proportion of their wealth in the form of government debt; since this debt does not grow, but the wealth does, they must put their resources somewhere else; their demand for equities is fixed; the only flexible element here are the deposits. The path that shows the proportion of government bonds in their wealth (figure 10) is just the opposite of their deposits' proportion (figure 11). Equities holdings are roughly the same for all rules (figure 12).

Figure 10. Government bonds as share of households' wealth under the four fiscal rules

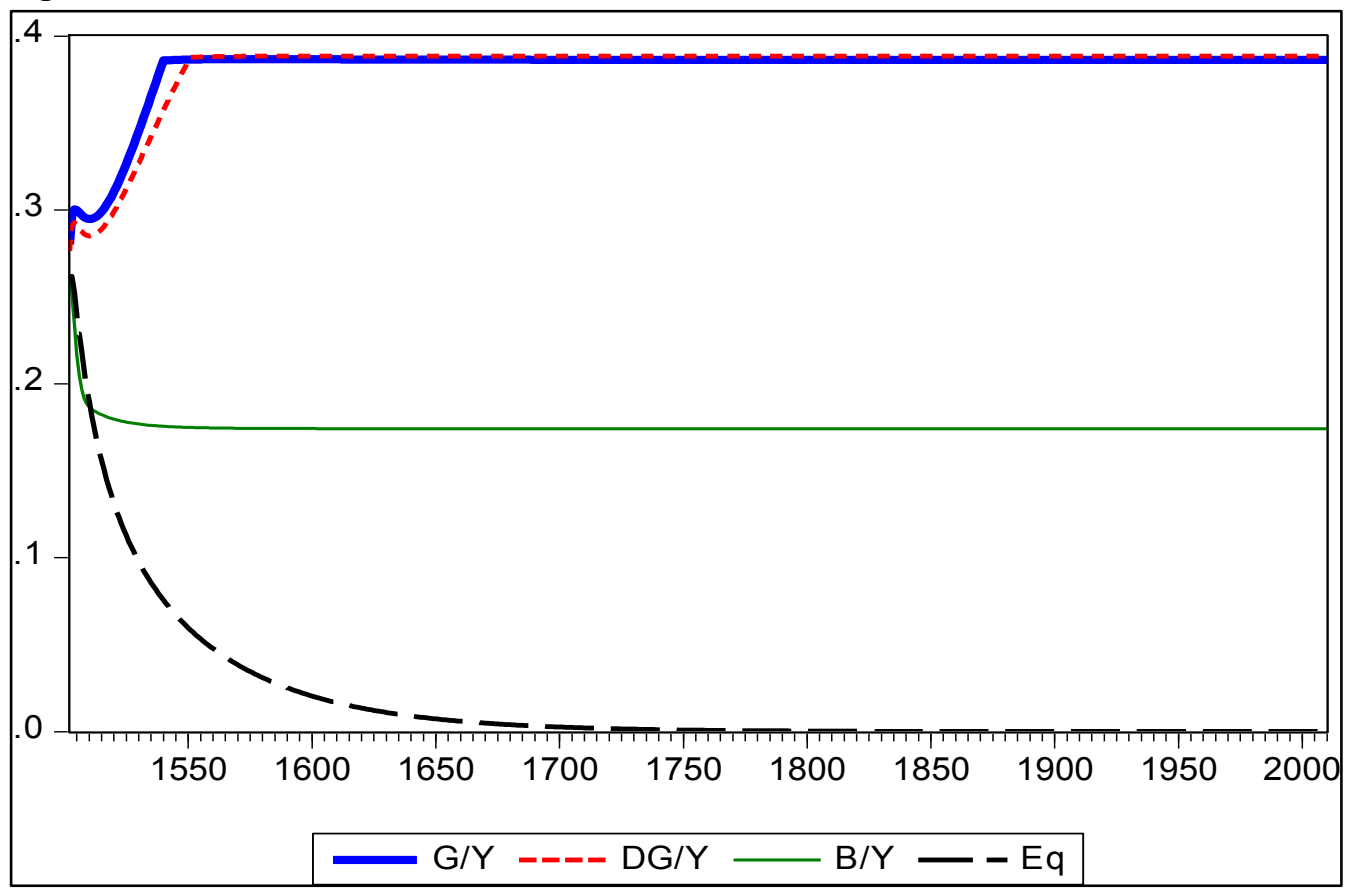

Source: Elaborated by the authors using Eviews. 
Figure 11. Deposits as share of households' wealth under the four fiscal rules

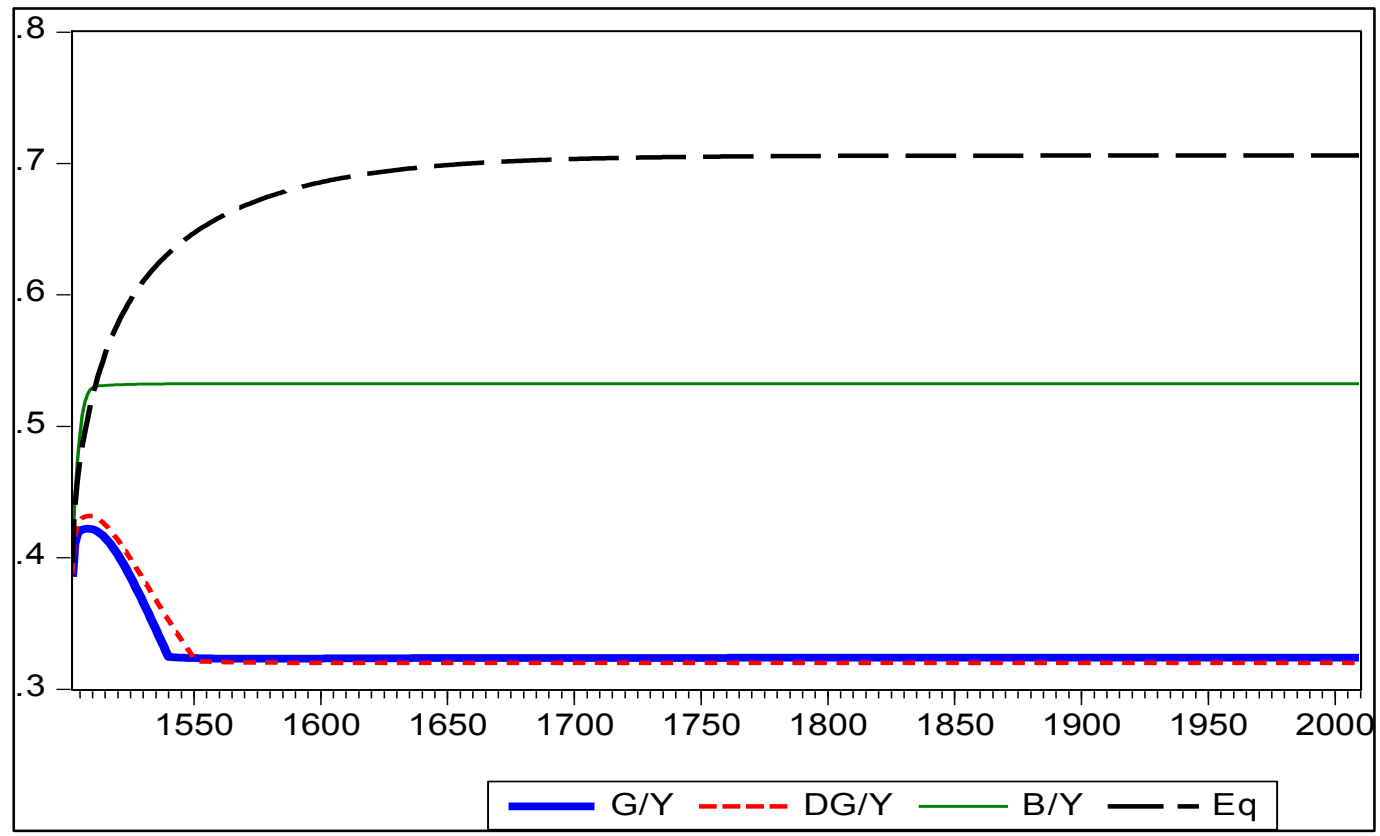

Source: Elaborated by the authors using Eviews.

Figure 12. Equities as share of households' wealth under the four fiscal rules

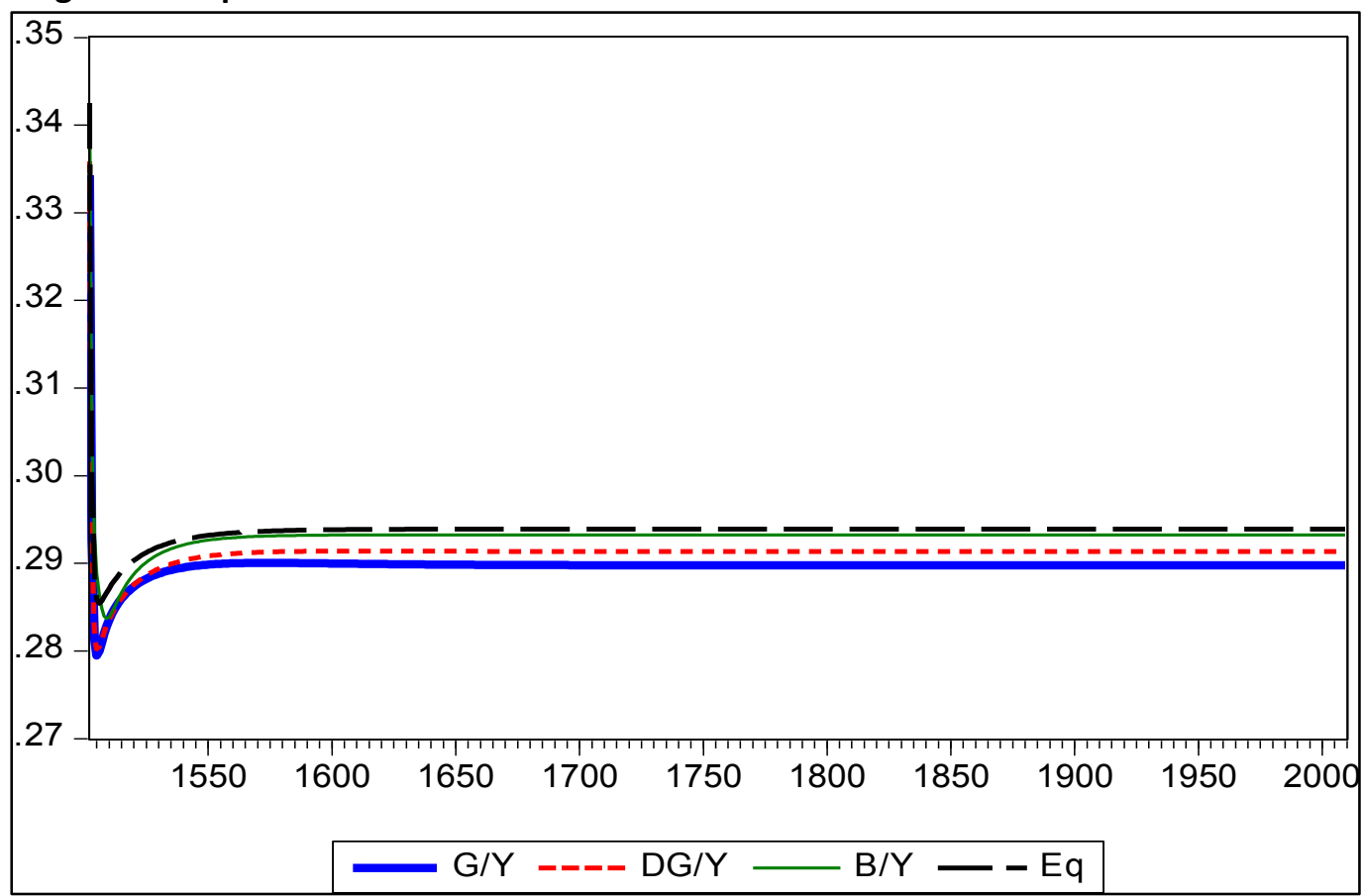

Source: Elaborated by the authors using Eviews.

It must be noted that, under the first two rules, households increase their holdings of government bonds until it reaches the desired level. In the last two rules, households are not able to reach their desired holdings of government bonds because there are not enough bonds available to them. In the $B / Y$ rule, this happens because government has a debt target that is below households' demand for bonds. Under the balanced budget rule, the government never runs a deficit, and hence there is no supply of new bonds (government bonds are not net wealth nor wealth at all). Equities prices reach diverse steady state values. The differences are 
caused by the growth rate of output, which increases households' wealth and thus the demand for equities (figure 13).

Figure 13. Equities' prices under the four fiscal rules

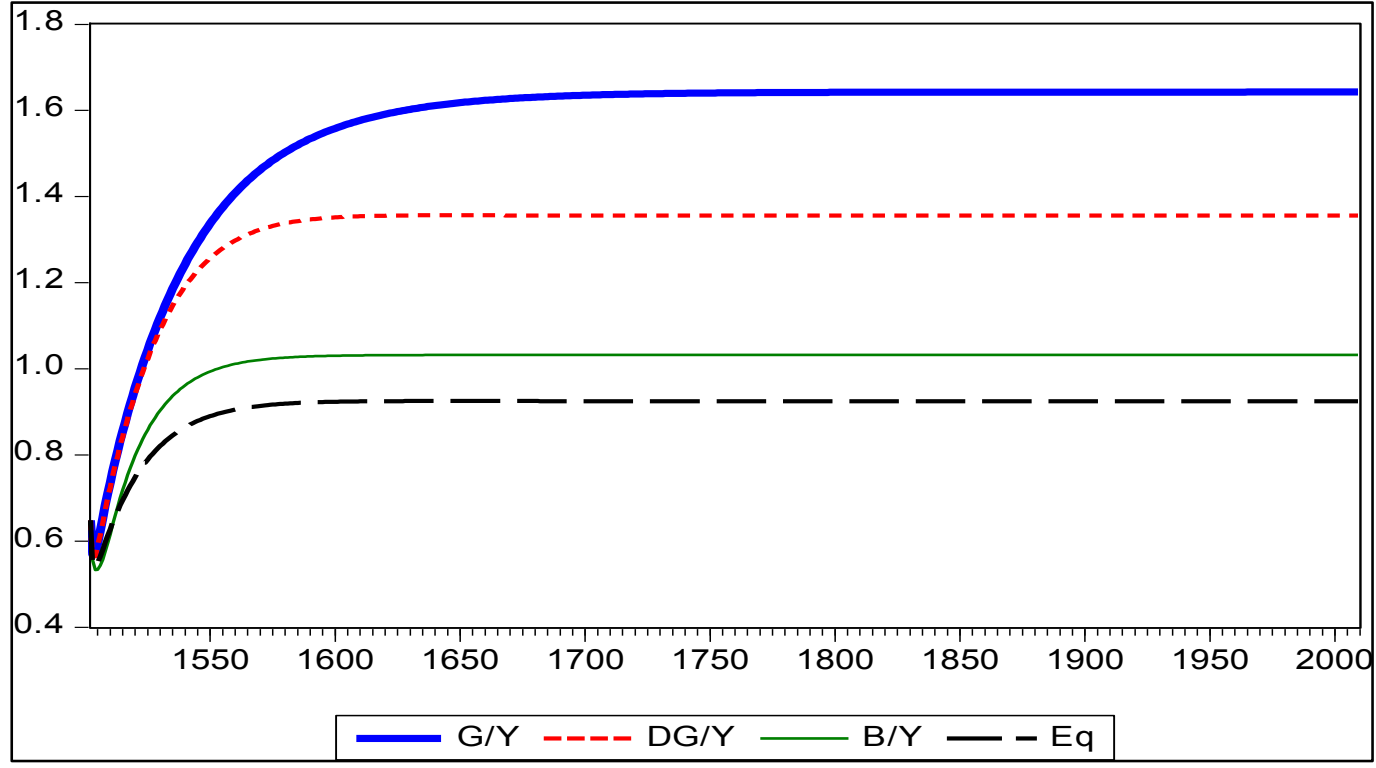

Source: Elaborated by the authors using Eviews.

The sources of investment finance are also correlated with economic activity. The higher the growth rate of the economy is, the higher the profits are, and, thus, the retained profits (figure 14), which reduces the demand for loans. This also boosts the issuance of equities (figure 15). Thus, the latter falls under the four fiscal rules (figure 16).

Figure 14. Share of investment financed with retained earnings under the four fiscal rules

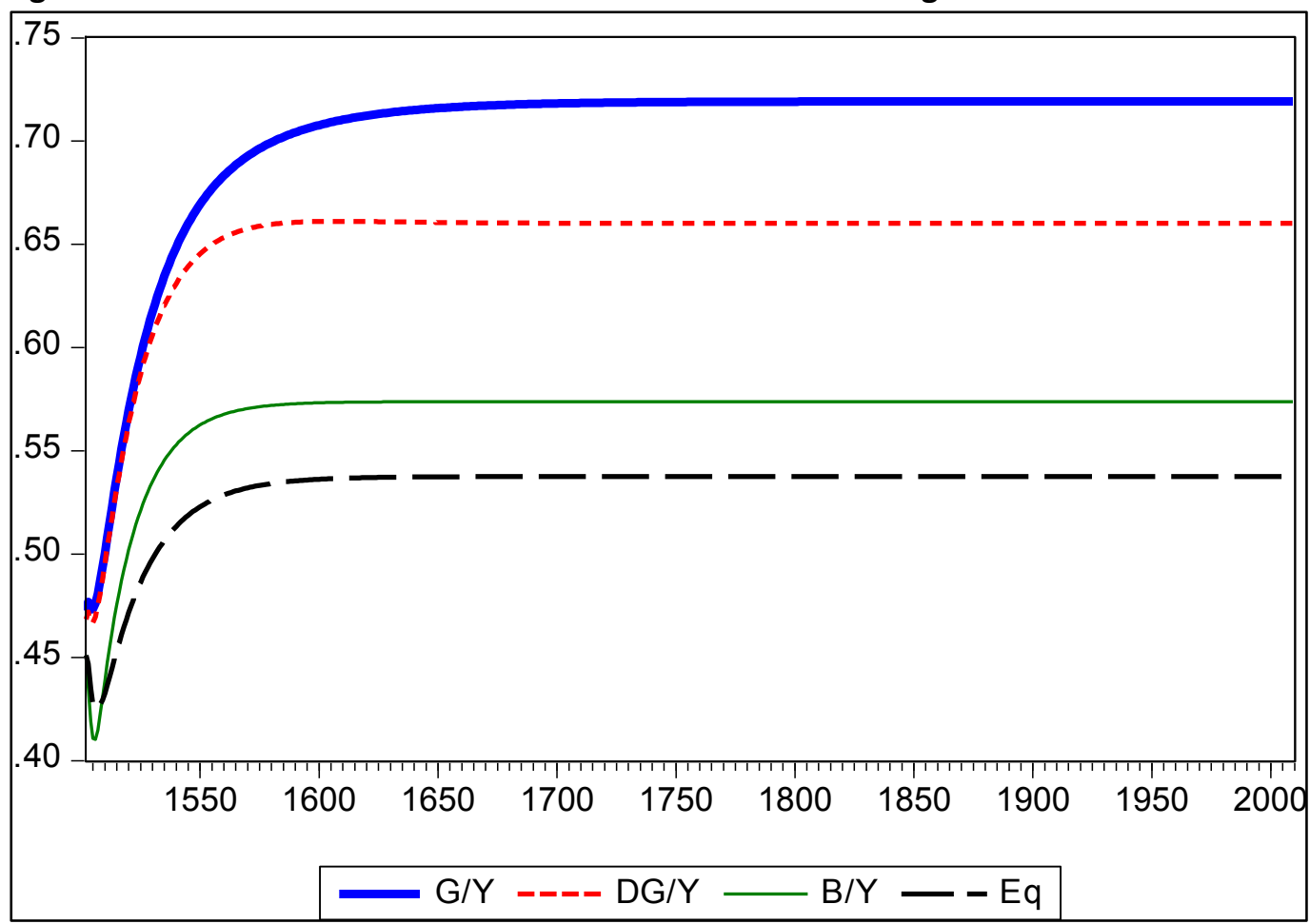

Source: Elaborated by the authors using Eviews. 
Figure 15. Share of investment financed with equities under the four fiscal rules

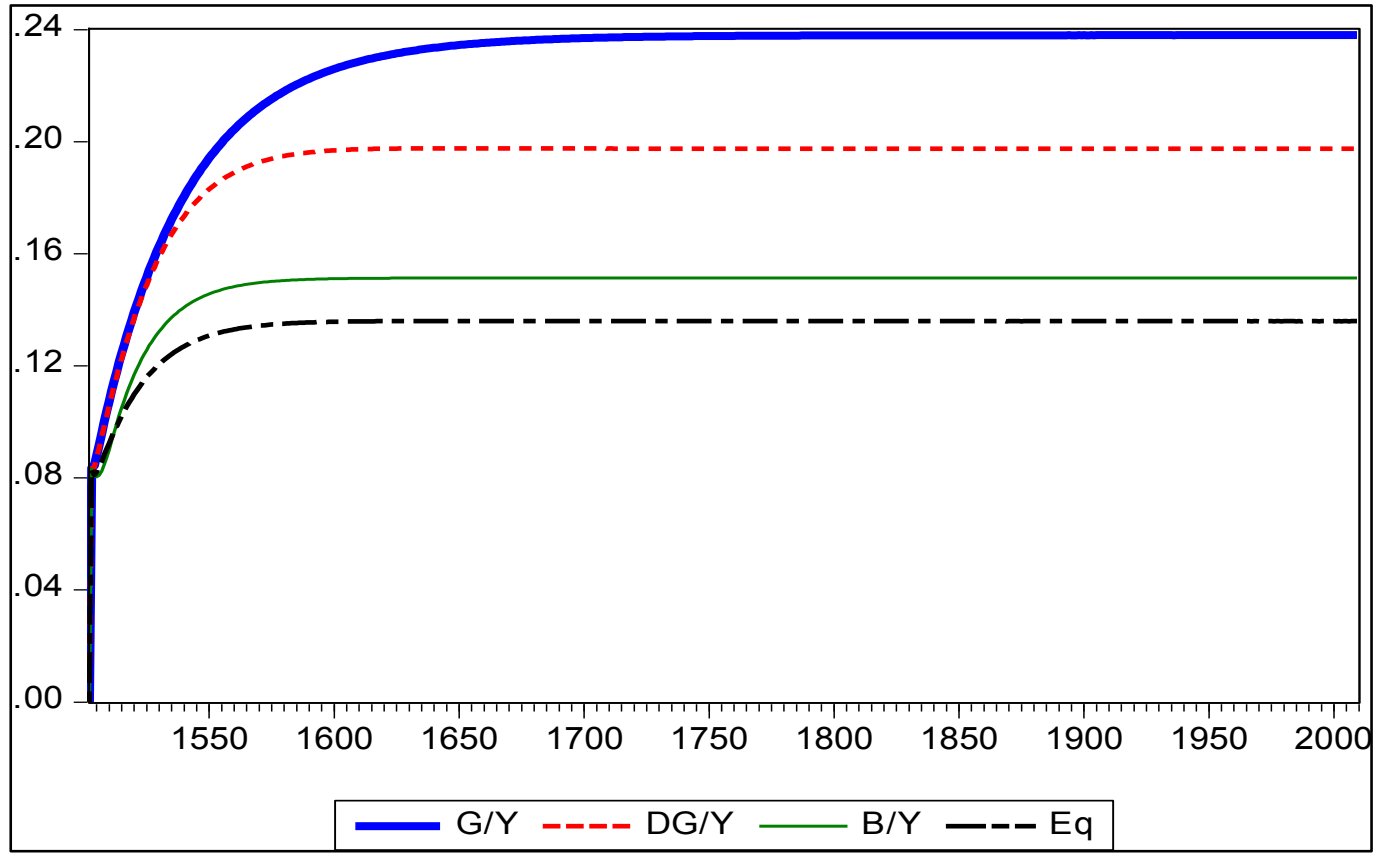

Source: Elaborated by the authors using Eviews.

Figure 16 - Share of investment financed with loans under the four fiscal rules

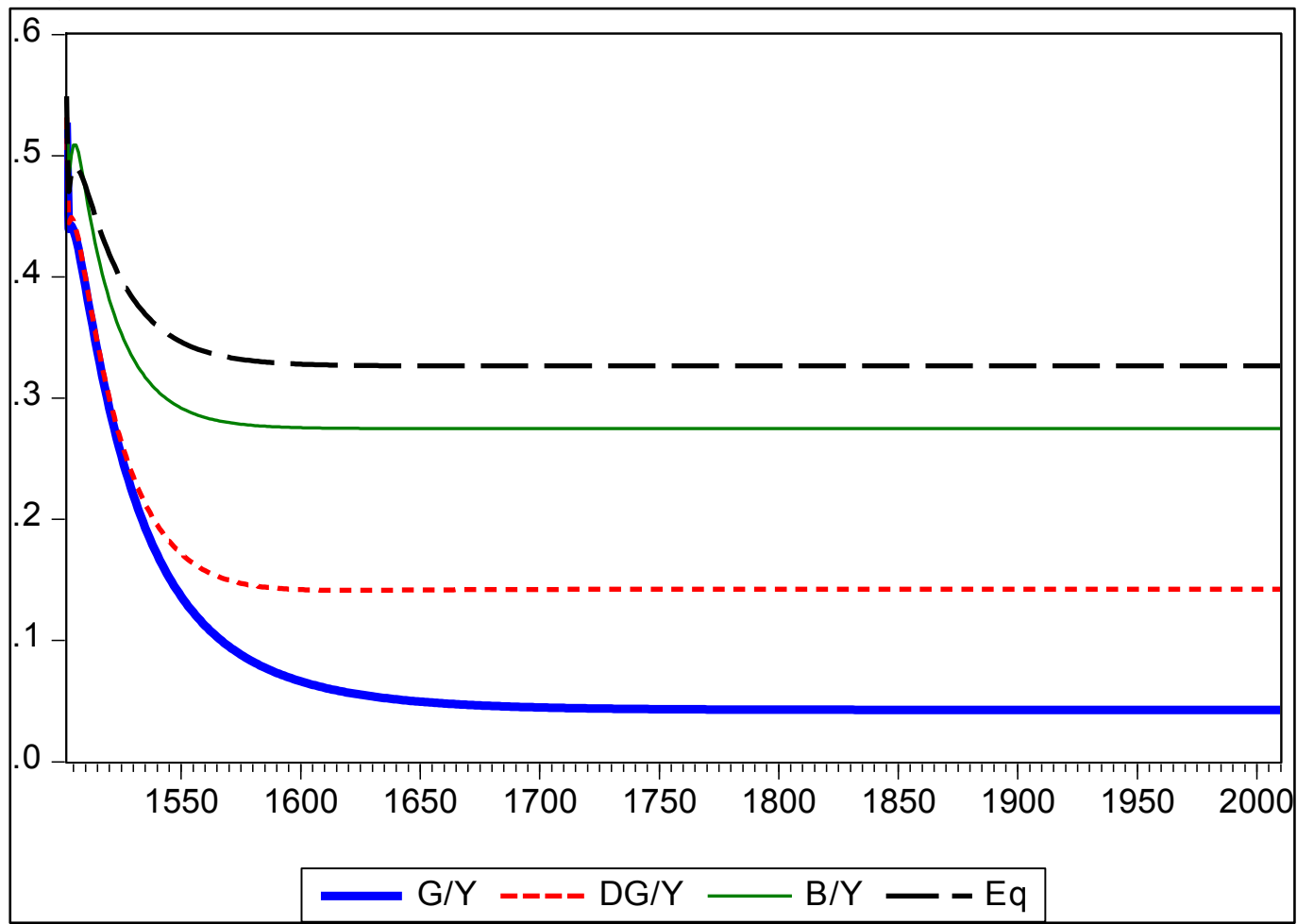

Source: Elaborated by the authors using Eviews.

The differences in the share of investment financed with loans are reflected in the firms' loans to capital ratio (leverage): the fixed G/Y rule, after pushing the leverage to 0.2 in the medium-run, has the lowest steady-state value (0.04), whereas the balanced budget rule has the highest one (0.32) (figure 17). 
Figure 17 - Firms' debt relative to the stock of capital under the four fiscal rules

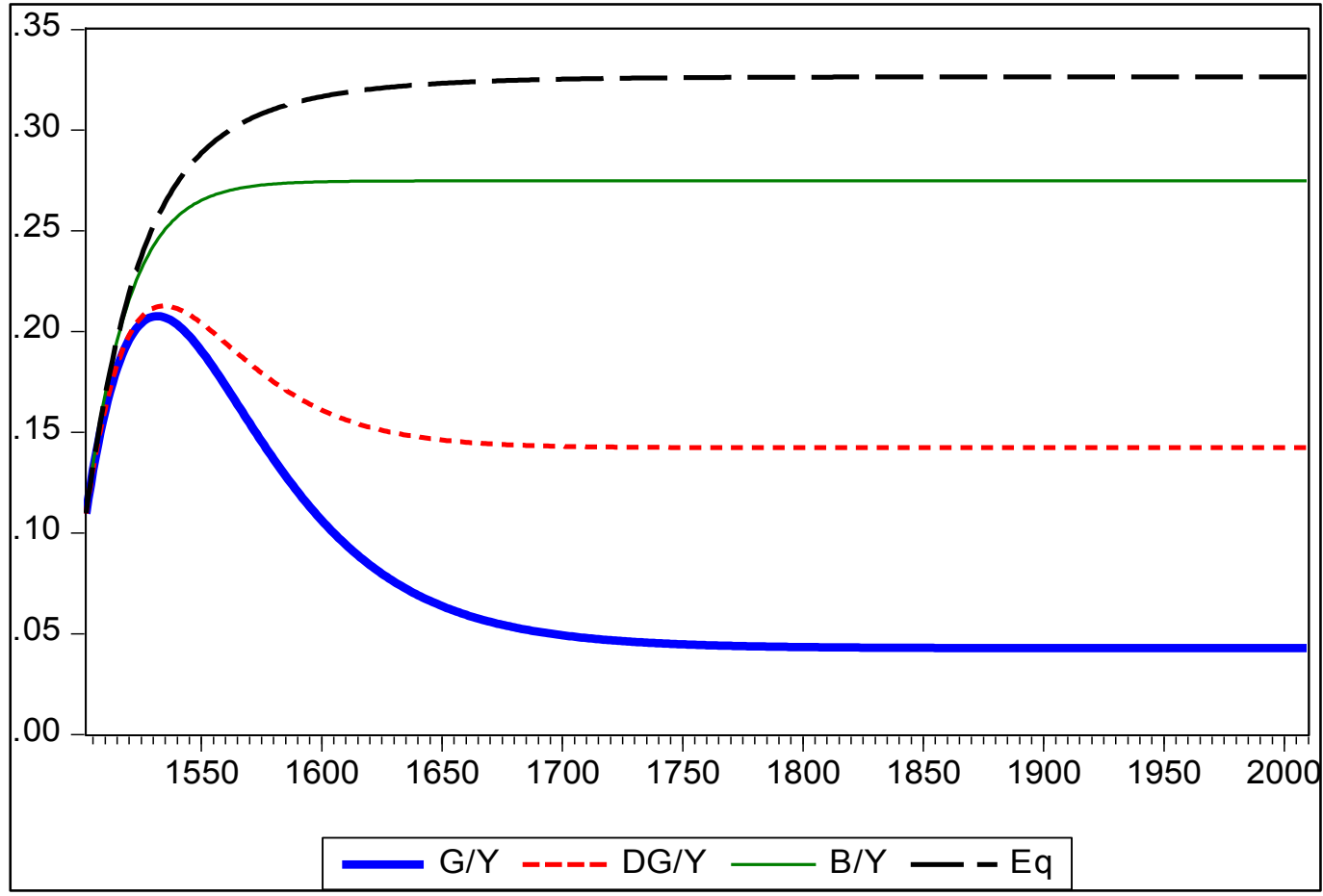

Source: Elaborated by the authors using Eviews.

Firms' indebtedness has impacts on banks' profitability. The regimes that generate lower indebtedness levels also generate lower profitability for banks, here defined as the ratio between profits and assets' holdings (government bonds, high powered money, and loans) or return on assets (ROA).

Figure 18 - Banks' profits relative to the value of its assets (ROA) under the four fiscal rules

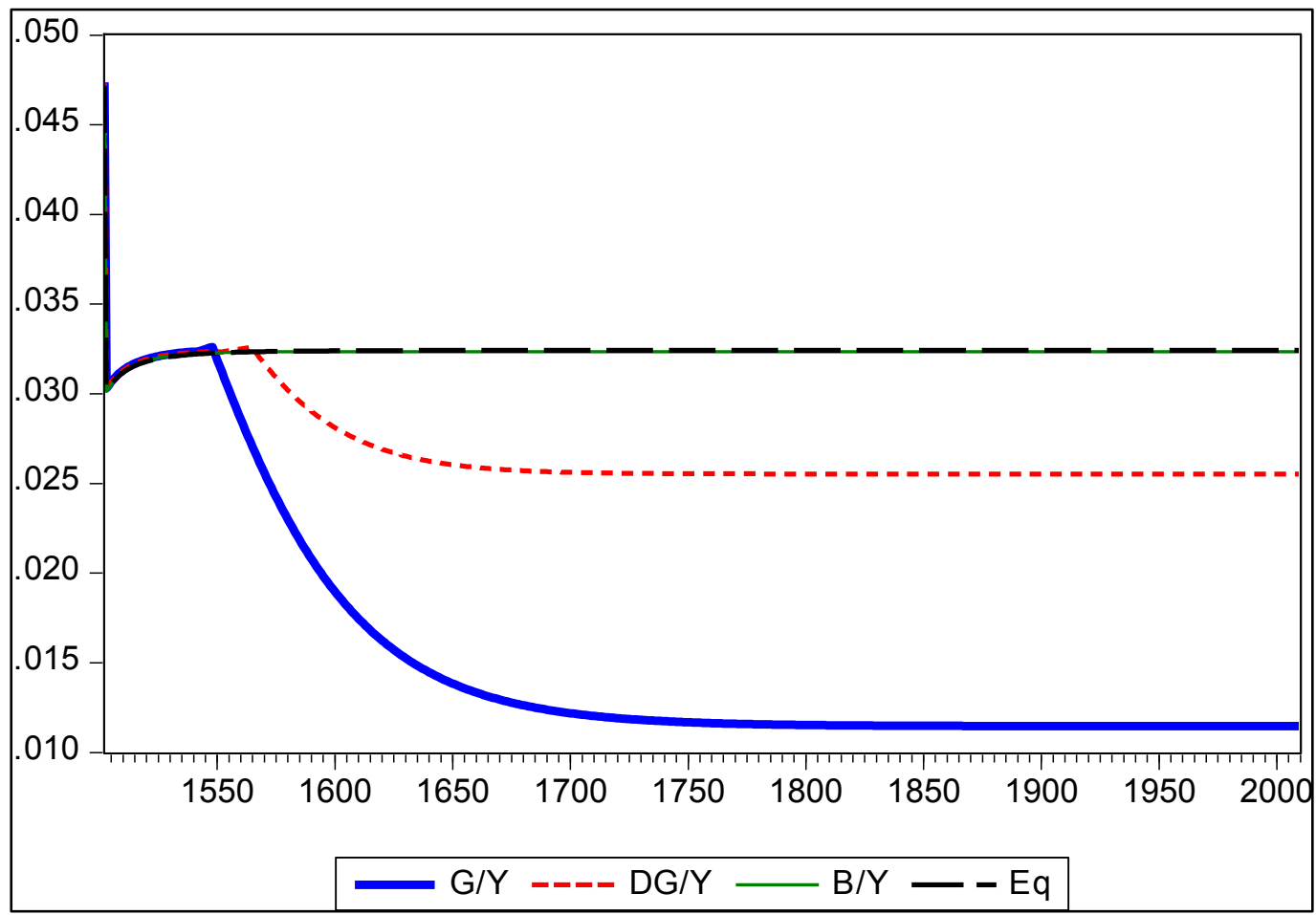

Source: Elaborated by the authors using Eviews. 
Finally, we can summarize the most important relationships analyzed above. The first fiscal rule, in which the government seeks to maintain a fixed proportion of spending relative to GDP, is the one that generates the highest growth rate and, consequently, the highest capacity utilization rate and firms' profitability, but surprisingly the lowest investment levels. The behavior of the latter generates a lower loan to capital ratio, since firms generate more internal resources to finance their investment orders. A lower firm indebtedness (leverage) reduces banks' profitability. A consequence of the maintenance of government expenditures as a constant share of output regardless of any deficit or debt size considerations is the relatively bigger size of its debt, which is the highest among the four fiscal rules. Since government debt is also private wealth, this higher debt level has its counterpart in a higher ratio of financial wealth to the stock of capital.

The opposite happens under the balanced budget rule, the closest one to the fiscal rule adopted by the Brazilian government. Lower government consumption causes a lower growth rate. This is reflected in lower capacity utilization and meager firms' profits, which reduces their internal resources, forcing them to use more loans as a mean to finance investment expenditures, whose levels are relatively higher. The consequence of this is a higher profitability for banks. Since the government budget is balanced, it does not generate deficits and new debts. Households' wealth to capital ratio is the lowest one under this rule.

\section{Concluding Remarks}

In this paper, a simple SFC model was developed in order to analyze the macroeconomic impacts of four different fiscal policy rules. Some of the main conclusions can be summarized as follows: the more expansionist (or less contractionist) rules present higher output growth rates; there is an inverse relationship between government debt and firms' debt, with government debt reaching the highest steady-state plateau under the $G / Y$ rule, and the lowest under the balanced budget rule, the opposite happening in the case of firms' debt. Analyzing profitability, we conclude that the best scenario for firms is the one under the $G / Y$ rule, and, for the banking sector, not surprisingly, it is the balanced budget rule.

If these results can be extrapolated to the Brazilian experience, then the new fiscal austerity policies in Brazil are likely to deliver poor macroeconomic results. They are likely to reduce long-term growth rates, increase idle capacity, boost consumption to the detriment of investment, and beef up banks' profits. The model, however, has many shortcomings that may hinder these results. It ignores inflation, households' indebtedness, inventories accumulation, and supply side constraints. It also presents very simplified portfolio choices and a naïve wage bargaining process. The calibration of the model also is problematic, since it was not intended to simulate a specific economy, and it still lacks econometric support. A consequence of all these drawbacks is some unrealistic results of the model, such as the very low capacity utilization rates and low investment rates, and the existence of positive investment levels in the presence of very low utilization rates. This result was not discussed in deep, but it may find some explanations in Marx's argument about coerced investment. These problems are relevant must be dealt with in future works.

\section{References}

Benati, L. and Lubik, T. A. (2014) "Sales, Inventories and Real Interest Rates: A Century of Stylized Facts", Journal of Applied Econometrics, 29(7), p. 1210-1222.

Blanchard, O. (2016) "Do DSGE models have a future?", Peterson Institute for International Economics, Policy Brief, 16-11. 
Blanchard, O. J. and Leigh, D. (2013) "Growth forecast errors and fiscal multipliers", American Economic Review, 103(3), p. 117-120.

Borsi, M. T. (2016) "Fiscal multipliers across the credit cycle", Banco de España, documentos de trabajo, n. 1618.

Burgess, S., Burrows, O., Godin, A., Kinsella, S., and Millard, S. (2016) "A dynamic model of financial balances for the United Kingdom", Bank of England Staff Working Paper, $n$. 614.

Cavalcante, L. R., De Negri, F. (2014) "Evolução recente dos indicadores de produtividade no brasil." In.: De Negri, F.; Cavalcante, L. R. (Eds), Produtividade no Brasil: desempenho e determinantes - Volume 1: Desempenho. Brasília: ABDI, IPEA.

Crotty, J. (1993) "Rethinking Marxian Investment Theory: Keynes-Minsky Instability, Competitive Regime Shifts and Coerced Investment", Review of Radical Political Economics, 25(1), p. 1-26.

Dafermos, Y. (2012) "Liquidity preference, uncertainty, and recession in a stock-flow consistent model", Journal of Post Keynesian Economics, v. 34(4), p. 749-776.

Denis, D. J. and Sibilkov, V. (2009) "Financial constraints, investment, and the value of cash holdings", Review of Financial Studies, 23(1), p. 247-269.

Dos Santos, C.H. (2002) Three Essays in Stock-Flow Consistent Macroeconomic Modeling. PhD Dissertation, New School University.

Dos Santos, C. H. and Zezza, G. (2008) "A simplified, 'benchmark', stock-flow consistent postkeynesian growth model", Metroeconomica, 59(3), p. 441-478.

Godley, W. (1996) "Money, finance and national income determination: an integrated approach", Jerome Levy Economics Institute Working paper, n. 167, Bard College.

Godley, W. and Lavoie, M. (2007) Monetary Economics: an integrated approach to credit, money, income, production and wealth. New York: Palgrave Macmillan.

Hatzius, J. and Stehn, J. (2012) "The US Economy in 2013-2016: Moving Over the Hump", Goldman Sachs US Economics Analyst, n. 12/48.

IMF (2016) “Brazil”. IMF Country Report, n. 16/348.

Kalecki, M. (1965) Theory of Economic Dynamics. London: Allen and Unwin, $2^{\text {nd }}$ edition.

Keen, S. (2017) "The WHO warns of outbreak of virulent new 'Economic Reality' virus", Review of Keynesian Economics, 5(1), p. 107-111.

Klein, M. (2016) "Austerity and private debt", Ruhr Economic Papers, n. 642.

Lavoie, M. (2008) "Financialisation issues in a Post-Keynesian stock-flow consistent model", Interventions - European Journal of Economics and Economic Policies, 5(2), p. 335-361.

Lavoie, M. and Godley, W. (2001-2002) "Kaleckian models of growth in a coherent stock-flow monetary framework: a Kaldorian view", Journal of Post Keynesian Economics, 24(2), p. 277-311. 
Le Heron, E. (2012) "A Debate with Wynne Godley on the Neutrality of Fiscal Policy". In: D. Papadimitriou and G. Zezza (eds.) Contributions to Stock-Flow Modeling: Essays in Honor of Wynne Godley. London: Palgrave Macmillan.

Le Heron, E. and Mouakil, T. (2008) "A post-keynesian stock-flow consistent model for dynamic analysis of monetary policy shock on banking behaviour", Metroeconomica, 59(3), p. 405-440.

Mian, A. R., Sufi, A. and Verner, E. (2015) "Household debt and business cycles worldwide", National Bureau of Economic Research, working paper, n. 21581.

Ostry, J. D., Loungani, P; and Furceri, D. (2016) "Neoliberalism: Oversold?", Finance \& Development, June, 53(2), p. 38-41.

Pedrosa, I. and Macedo e Silva, A. C. (2014) "A Minskyan-Fisherian SFC model for analyzing the linkages of private financial behavior and public debt". 18th FMM Conference: "Inequality and the Future of Capitalism", Berlin. Available on https://www.boeckler.de/pdf/v_2014_10_30_pedrosa_macedo_e_silva.pdf. Accessed on $25 / 06 / 2016$.

Romer, P. (2016) "The trouble with macroeconomics", Available at: $<$ https://paulromer.net/wp-content/uploads/2016/09/WP-Trouble.pdf>. Accessed on 23/04/2017.

Steindl, J. (1952) Maturity and Stagnation in American Capitalism. Oxford: Blackwell. 